4

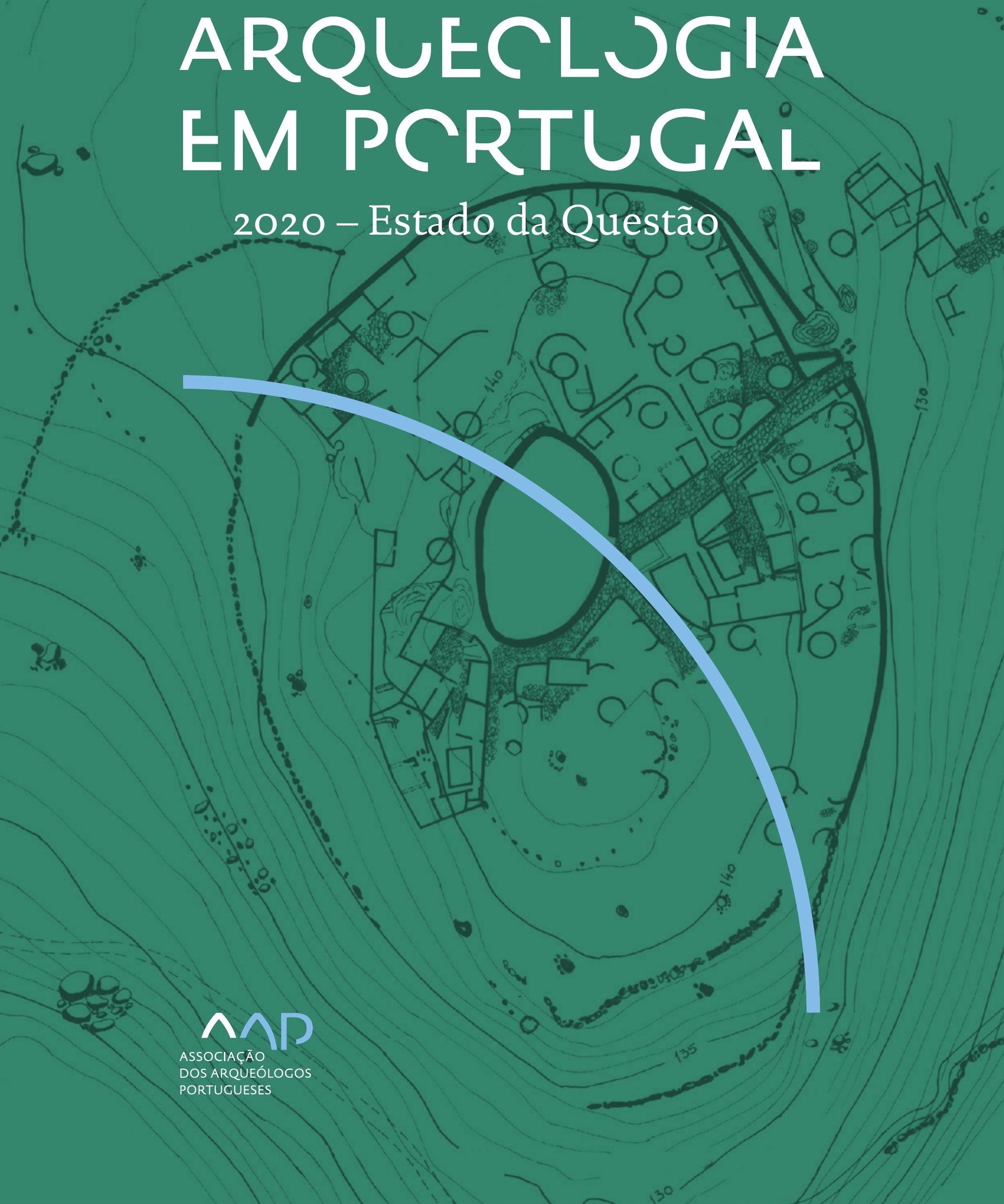


Coordenação editorial: José Morais Arnaud, César Neves e Andrea Martins Design gráfico: Flatland Design

AAP - ISBN: 978-972-9451-89-8

CITCEM - ISBN: 978-989-8970-25-1

Associação dos Arqueólogos Portugueses e CITCEM

Lisboa, 2020

O conteúdo dos artigos é da inteira responsabilidade dos autores. Sendo assim a Associação dos Arqueólogos Portugueses declina qualquer responsabilidade por eventuais equívocos ou questões de ordem ética e legal.

Desenho de capa:

Planta do castro de Monte Mozinho (Museu Municipal de Penafiel).

\section{$\hat{\wedge} \mathrm{P}$}

DOS ARQUEÓLOGOS PORTUGUESES

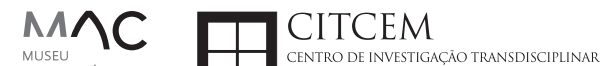
MUSEU
ARQUELLÓGICO
DO CARMO
U.PORTO

FLUP FACULDADE DE LETRAS
UNIVERSIDADE DO PORTO

Apoio

EC para a Ciência 


\section{Índice}

15 Prefácio

José Morais Arnaud

\section{Historiografia e Teoria}

17 Território, comunidade, memória e emoção: a contribuição da história da arqueologia (algumas primeiras e breves reflexões)

Ana Cristina Martins

25 Como descolonizar a arqueologia portuguesa?

Rui Gomes Coelho

41 Arqueologia e Modernidade: uma revisitação pessoal e breve de alguns aspetos da obra homónima de Julian Thomas de 2004

Vítor Oliveira Jorge

57 Dados para a História das Mulheres na Arqueologia portuguesa, dos finais do século XIX aos inícios do século XX: números, nomes e tabelas

Filipa Dimas / Mariana Diniz

73 Retractos da arqueologia portuguesa na imprensa: (in)visibilidades no feminino

Catarina Costeira / Elsa Luís

85 Arqueologia e Arqueólogos no Norte de Portugal Jacinta Bugalhão

101 Vieira Guimarães (1864-1939) e a arqueologia em Tomar: uma abordagem sobre o território e as gentes

João Amendoeira Peixoto / Ana Cristina Martins

115 Os memoráveis? A arqueologia algarvia na imprensa nacional e regional na presente centúria (2001-2019): características, visões do(s) passado(s) e a arqueologia

enquanto marca

Frederico Agosto / João Silva

129 A Evolução da Arqueologia Urbana e a Valorização Patrimonial no Barlavento Algarvio: Os casos de Portimão e Silves

Artur Mateus / Diogo Varandas / Rafael Boavida

\section{Gestão, Valorização e Salvaguarda do Património}

145 O Caderno Reivindicativo e as condições de trabalho em Arqueologia Miguel Rocha / Liliana Matias Carvalho / Regis Barbosa / Mauro Correia / Sara Simões / Jacinta Bugalhão / Sara Brito / Liliana Veríssimo Carvalho / Richard Peace / Pedro Peça / Cézer Santos

155 Os Estudos de Impacte Patrimonial como elemento para uma estratégia sustentável de minimização de impactes no âmbito de reconversões agrícolas Tiago do Pereiro

165 Salvaguarda de Património arqueológico em operações florestais: gestão e sensibilização Filipa Bragança / Gertrudes Zambujo / Sandra Lourenço / Belém Paiva / Carlos Banha / Frederico Tatá Regala / Helena Moura / Jacinta Bugalhão / João Marques / José Correia / Pedro Faria / Samuel Melro

179 Os valores do Património: uma investigação sobre os Sítios Pré-históricos de Arte Rupestre do Vale do Rio Côa e de Siega Verde José Paulo Francisco 
189 Conjugando recursos arqueológicos e naturais para potenciar as visitas ao Geoparque Litoral de Viana do Castelo (Noroeste de Portugal)

Hugo A. Sampaio / Ana M.S. Bettencourt / Susana Marinho / Ricardo Carvalhido

203 Áreas de Potencial Arqueológico na Região do Médio Tejo: Modelo Espacial Preditivo Rita Ferreira Anastácio / Ana Filipa Martins / Luiz Oosterbeek

223 Património Arqueológico e Gestão Territorial: O contributo da Arqueologia para a revisão do PDM de Avis

Ana Cristina Ribeiro

237 A coleção arqueológica do extinto Museu Municipal do Porto - Origens, Percursos e Estudos

Sónia Couto

251 Valpaços - uma nova carta arqueológica

Pedro Pereira / Maria de Fátima Casares Machado

263 Arqueologia na Cidade de Peniche

Adriano Constantino / Luís Rendeiro

273 Arqueologia Urbana: a cidade de Lagos como caso de Estudo Cátia Neto

285 Estratégias de promoção do património cultural subaquático nos Açores. O caso da ilha do Faial

José Luís Neto / José Bettencourt / Luís Borges / Pedro Parreira

297 Carta Arqueológica da Cidade Velha: Uma primeira abordagem

Jaylson Monteiro / Nireide Tavares / Sara da Veiga / Claudino Ramos / Edson Brito /

Carlos Carvalho / Francisco Moreira / Adalberto Tavares

311 Antropologia Virtual: novas metodologias para a análise morfológica e funcional Ricardo Miguel Godinho / Célia Gonçalves

\section{Didáctica da Arqueologia}

327 Como os projetos de Arqueologia podem contribuir para uma comunidade culturalmente mais consciente Alexandra Figueiredo / Claúdio Monteiro / Adolfo Silveira / Ricardo Lopes

337 Educação Patrimonial - Um cidadão esclarecido é um cidadão ativo! Ana Paula Almeida

351 A aproximação da Arqueologia à sala de aula: um caso de estudo no $3^{\circ}$ ciclo do Ensino Básico Luís Serrão Gil

363 Arqueologia 3.o - Pensar e comunicar a Arqueologia para um futuro sustentável Mónica Rolo

377 “Conversa de Arqueólogos" - Divulgar a Arqueologia em tempos de Pandemia Diogo Teixeira Dias

389 Escola Profissional de Arqueologia: desafios e oportunidades Susana Nunes / Dulcineia Pinto / Júlia Silva / Ana Mascarenhas

399 Os Museus de Arqueologia e os Jovens: a oferta educativa para o público adolescente Beatriz Correia Barata / Leonor Medeiros

411 O museu universitário como mediador entre a ciência e a sociedade: o exemplo da secção de arqueologia no Museu de História Natural e da Ciência da Universidade do Porto (MHNC-UP)

Rita Gaspar 
421 Museu de Lanifícios: Real Fábrica de Panos. Atividades no âmbito da Arqueologia Beatriz Correia Barata / Rita Salvado

427 Arqueologia Pública e o caso da localidade da Mata (Torres Novas) Cláudia Manso / Ana Rita Ferreira / Cristiana Ferreira / Vanessa Cardoso Antunes

431 Do sítio arqueológico ao museu: um percurso (também) didático Lídia Fernandes

447 Estão todos convidados para a Festa! E para dançar também... O projecto do Serviço Educativo do Museu Arqueológico do Carmo na $5^{\underline{a}}$ Edição da Festa da Arqueologia Rita Pires dos Santos

459 O “Clã de Carenque”, um projeto didático de arqueologia Eduardo Gonzalez Rocha

469 Mediação cultural: peixe que puxa carroça nas Ruínas Romanas de Troia Inês Vaz Pinto / Ana Patrícia Magalhães / Patrícia Brum / Filipa Santos

481 Didática Arqueológica, experiências do Projeto Mértola Vila Museu Maria de Fátima Palma / Clara Rodrigues / Susana Gómez / Lígia Rafael

\section{Arte Rupestre}

497 Os inventários de arte rupestre em Portugal Mila Simões de Abreu

513 O projeto FIRST-ART - conservação, documentação e gestão das primeiras manifestações de arte rupestre no Sudoeste da Península Ibérica: as grutas do Escoural e Maltravieso Sara Garcês / Hipólito Collado / José Julio García Arranz / Luiz Oosterbeek / António Carlos Silva / Pierluigi Rosina / Hugo Gomes / Anabela Borralheiro Pereira / George Nash / Esmeralda Gomes / Nelson Almeida / Carlos Carpetudo

523 Trabalhos de documentação de arte paleolítica realizados no âmbito do projeto PalæoCôa André Tomás Santos / António Fernando Barbosa / Luís Luís / Marcelo Silvestre / Thierry Aubry

537 Imagens fantasmagóricas, silhuetas elusivas: as figuras humanas na arte do Paleolítico Superior da região do Côa Mário Reis

$55^{1}$ Os motivos zoomórficos representados nas placas de tear de Vila Nova de São Pedro (Azambuja, Portugal) Andrea Martins / César Neves / José M. Arnaud / Mariana Diniz

571 Arte Rupestre do Monte de Góios (Lanhelas, Caminha). Síntese dos resultados dos trabalhos efectuados em 2007-2009 Mário Varela Gomes

599 Gravuras rupestres de barquiformes no Monte de S. Romão, Guimarães, Noroeste de Portugal Daniela Cardoso

613 Círculos segmentados gravados na Bacia do Rio Lima (Noroeste de Portugal): contributos para o seu estudo Diogo Marinho / Ana M.S. Bettencourt / Hugo Aluai Sampaio

631 Equídeos gravados no curso inferior do Rio Mouro, Monção (NW Portugal). Análise preliminar Coutinho, L.M. / Bettencourt, A.M.S / Sampaio, Hugo A.S

645 Paletas na Arte Rupestre do Noroeste de Portugal. Inventário preliminar Bruna Sousa Afonso / Ana M. S. Bettencourt / Hugo A. Sampaio 


\section{Pré-História}

661 O projeto Miño/Minho: balanço de quatro anos de trabalhos arqueológicos Sérgio Monteiro-Rodrigues / João Pedro Cunha-Ribeiro / Eduardo Méndez-Quintas / Carlos Ferreira / Pedro Xavier / José Meireles / Alberto Gomes / Manuel Santonja / Alfredo Pérez-González

677 A ocupação paleolítica da margem esquerda do Baixo Minho: a indústria lítica do sítio de Pedreiras 2 (Monção, Portugal) e a sua integração no contexto regional Carlos Ferreira / João Pedro Cunha-Ribeiro / Sérgio Monteiro-Rodrigues / Eduardo Méndez-Quintas / Pedro Xavier / José Meireles / Alberto Gomes / Manuel Santonja / Alfredo Pérez-González

693 O sítio acheulense do Plistocénico médio da Gruta da Aroeira Joan Daura / Montserrat Sanz / Filipa Rodrigues / Pedro Souto / João Zilhão

703 As sociedades neandertais no Barlavento algarvio: modelos preditivos com recurso aos SIG

Daniela Maio

715 A utilização de quartzo durante o Paleolítico Superior no território dos vales dos rios Vouga e Côa

Cristina Gameiro / Thierry Aubry / Bárbara Costa / Sérgio Gomes / Luís Luís / Carmen Manzano / André Tomás Santos

733 Uma perspetiva diacrónica da ocupação do concheiro do Cabeço da Amoreira (Muge, Portugal) a partir da tecnologia lítica Joana Belmiro / João Cascalheira / Célia Gonçalves

745 Novos dados sobre a Pré-história Antiga no concelho de Palmela. A intervenção arqueológica no sítio do Poceirão I

Michelle Teixeira Santos

757 Problemas em torno de Datas Absolutas Pré-Históricas no Norte do Alentejo Jorge de Oliveira

771 Povoamento pré-histórico nas áreas montanhosas do NO de Portugal: o Abrigo 1 de Vale de Cerdeira Pedro Xavier / José Meireles / Carlos Alves

783 Apreciação do povoamento do Neolítico Inicial na Baixa Bacia do Douro. A Lavra I (Serra da Aboboreira) como caso de estudo Maria de Jesus Sanches

797 O Processo de Neolitização na Plataforma do Mondego: os dados do Sector C do Outeiro dos Castelos de Beijós (Carregal do Sal)

João Carlos de Senna-Martinez / José Manuel Quintã Ventura / Andreia Carvalho / Cíntia Maurício

823 Novos trabalhos na Lapa da Bugalheira (Almonda, Torres Novas) Filipa Rodrigues / Pedro Souto / Artur Ferreira / Alexandre Varanda / Luís Gomes / Helena Gomes / João Zilhão

837 A pedra polida e afeiçoada do sítio do Neolítico médio da Moita do Ourives (Benavente, Portugal)

César Neves

857 Casal do Outeiro (Encarnação, Mafra): novos contributos para o conhecimento do povoamento do Neolítico final na Península de Lisboa.

Cátia Delicado / Carlos Maneira e Costa / Marta Miranda / Ana Catarina Sousa

873 Stresse infantil, morbilidade e mortalidade no sítio arqueológico do Neolítico Final/ Calcolítico ( $4^{\circ}$ e $3^{\circ}$ milénio a.C.) do Monte do Carrascal 2 (Ferreira do Alentejo, Beja) Liliana Matias de Carvalho / Sofia N. Wasterlain 
885 Come together: O Conjunto Megalítico das Motas (Monção, Viana do Castelo) e as expressões Campaniformes do Alto Minho Ana Catarina Basílio / Rui Ramos

899 Trabalhos arqueológicos no sítio Calcolítico da Pedreira do Poio Carla Magalhães / João Muralha / Mário Reis / António Batarda Fernandes

913 O sítio arqueológico de Castanheiro do Vento. Da arquitectura do sítio à arquitectura de um território João Muralha Cardoso

925 Estudo zooarqueológico das faunas do Calcolítico final de Vila Nova de São Pedro (Azambuja, Portugal): Campanhas de 2017 e 2018 Cleia Detry / Ana Catarina Francisco / Mariana Diniz / Andrea Martins / César Neves / José Morais Arnaud

943 As faunas depositadas no Museu Arqueológico do Carmo provenientes de Vila Nova de São Pedro (Azambuja): as campanhas de 1937 a 1967 Ana Catarina Francisco / Cleia Detry / César Neves / Andrea Martins / Mariana Diniz / José Morais Arnaud

959 Análise funcional de material lítico em sílex do castro de Vila Nova de S. Pedro (Azambuja, Portugal): uma primeira abordagem Rafael Lima

971 O recinto da Folha do Ouro 1 (Serpa) no contexto dos recintos de fossos calcolíticos alentejanos

António Carlos Valera / Tiago do Pereiro / Pedro Valério / António M. Monge Soares

\section{Proto-História}

987 Produção de sal marinho na Idade do Bronze do noroeste Português. Alguns dados para uma reflexão

Ana M. S. Bettencourt / Sara Luz / Nuno Oliveira / Pedro P. Simões / Maria Isabel C. Alves / Emílio Abad-Vidal

1001 A estátua-menir do Pedrão ou de São Bartolomeu do Mar (Esposende, noroeste de Portugal) no contexto arqueológico da fachada costeira de entre os rios Neiva e Cávado Ana M. S. Bettencourt / Manuel Santos-Estévez / Pedro Pimenta Simões / Luís Gonçalves

1015 O Castro do Muro (Vandoma/Baltar, Paredes) - notas para uma biografia de ocupação da Idade do Bronze à Idade Média

Maria Antónia D. Silva / Ana M. S. Bettencourt / António Manuel S. P. Silva / Natália Félix

1031 Do Bronze Final à Idade Média - continuidades e hiatos na ocupação de Povoados em Oliveira de Azeméis João Tiago Tavares / Adriaan de Man

1041 As faunas do final da Idade do Bronze no Sul de Portugal: leituras desde o Outeiro do Circo (Beja)

Nelson J. Almeida / Íris Dias / Cleia Detry / Eduardo Porfírio / Miguel Serra

1055 A Espada do Monte das Oliveiras (Serpa) - uma arma do Bronze Pleno do Sudoeste Rui M. G. Monge Soares / Pedro Valério / Mariana Nabais / António M. Monge Soares

1065 São Julião da Branca (Albergaria-a-Velha) - Investigação e valorização de um povoado do Bronze Final

António Manuel S. P. Silva / Paulo A. P. Lemos / Sara Almeida e Silva / Edite Martins de Sá

1083 Do castro de S. João ao Mosteiro de Santa Clara: notícia de uma intervenção arqueológica, em Vila do Conde Rui Pinheiro 
1095 O castro de Ovil (Espinho), um quarto de século de investigação - resultados e questões em aberto

Jorge Fernando Salvador / António Manuel S. P. Silva

1111 O Castro de Salreu (Estarreja), um povoado proto-histórico no litoral do Entre Douro e Vouga

Sara Almeida e Silva / António Manuel S. P. Silva / Paulo A. P. Lemos / Edite Martins de Sá

1127 Castro de Nossa Senhora das Necessidades (Sernancelhe): uma primeira análise artefactual Telma Susana O. Ribeiro

${ }_{1141}$ A cividade de Bagunte. O estado atual da investigação Pedro Brochado de Almeida

1153 Zoomorfos na cerâmica da Idade do Ferro no NW Peninsular: inventário, cronologias e significado Nuno Oliveira / Cristina Seoane

1163 Vasos gregos em Portugal: diferentes maneiras de contar a história do intercâmbio cultural na Idade do Ferro

Daniela Ferreira

1175 Os exotica da necrópole da Idade do Ferro do Olival do Senhor dos Mártires (Alcácer do Sal) no seu contexto regional

Francisco B. Gomes

\section{Antiguidade Clássica e Tardia}

1191 O uso de madeira como combustível no sítio da Quinta de Crestelos (Baixo Sabor): da Idade do Ferro à Romanização Filipe Vaz / João Tereso / Sérgio Simões Pereira / José Sastre / Javier Larrazabal Galarza / Susana Cosme / José António Pereira / Israel Espi

1207 Cultivos de Época Romana no Baixo Sabor: continuidade em tempos de mudança? João Pedro Tereso / Sérgio Simões Pereira / Filipe Santos / Luís Seabra / Filipe Vaz

1221 A casa romana na Hispânia: aplicação dos modelos itálicos nas províncias ibéricas Fernanda Magalhães / Diego Machado / Manuela Martins

1235 As pinturas murais romanas da Rua General Sousa Machado, n. ${ }^{5}$ 1, Chaves José Carvalho

1243 Trás do Castelo (Vale de Mir, Pegarinhos, Alijó) - Uma exploração agrícola romana do Douro

Tony Silvino / Pedro Pereira

1255 A sequência de ocupação no quadrante sudeste de Bracara Augusta: as transformações de uma unidade doméstica Lara Fernandes / Manuela Martins

1263 Os Mosaicos com decoração geométrica e geométrico-vegetalista dos sítios arqueológicos da área do Conuentus Bracaraugustanus. Novas abordagens quanto à conservação, restauro, decoração e datação Maria de Fátima Abraços / Licínia Wrench

1277 “Casa Romana” do Castro de São Domingos (Cristelos, Lousada): Escavação, Estudo e Musealização Paulo André de P. Lemos

1291 A arqueobotânica no Castro de Guifões (Matosinhos, Noroeste de Portugal): O primeiro estudo carpológico

Luís Seabra / Andreia Arezes / Catarina Magalhães / José Varela / João Pedro Tereso 
1305 Um Horreum Augustano na Foz do Douro (Monte do Castelo de Gaia, Vila Nova de Gaia) Rui Ramos

1311 Ponderais romanos na Lusitânia: padrões, formas, materiais e contextos de utilização Diego Barrios Rodríguez

1323 Um almofariz centro-itálico na foz do Mondego

Marco Penajoia

1335 Estruturas romanas de Carnide - Lisboa Luísa Batalha / Mário Monteiro / Guilherme Cardoso

1347 O contexto funerário do sector da "necrópole NO" da Rua das Portas de S. Antão (Lisboa): o espaço, os artefactos, os indivíduos e a sua interconectividade na interpretação do passado Sílvia Loja, José Carlos Quaresma, Nelson Cabaço, Marina Lourenço, Sílvia Casimiro, Rodrigo Banha da Silva, Francisca Alves-Cardoso

${ }_{1361}$ Povoamento em época Romana na Amadora - resultados de um projeto pluridisciplinar Gisela Encarnação / Vanessa Dias

1371 A Arquitectura Residencial em Mirobriga (Santiago do Cacém): contributo a partir de um estudo de caso Filipe Sousa / Catarina Felício

${ }_{1385}$ O fim do ciclo. Saneamento e gestão de resíduos nos edifícios termais de Mirobriga (Santiago do Cacém)

Catarina Felício / Filipe Sousa

1399 Balsa, Topografia e Urbanismo de uma Cidade Portuária Vítor Silva Dias / João Pedro Bernardes / Celso Candeias / Cristina Tété Garcia

1413 No Largo das Mouras Velhas em Faro (2017): novas evidências da necrópole norte de Ossonoba e da sua ocupação medieval Ricardo Costeira da Silva / Paulo Botelho / Fernando Santos / Liliana Nunes

1429 Instrumentos de pesca recuperados numa fábrica de salga em Ossonoba (Faro) Inês Rasteiro / Ricardo Costeira da Silva / Paulo Botelho

1439 A Necrópole Romana do Eirô, Duas Igrejas (Penafiel): intervenção arqueológica de 2016 Laura Sousa / Teresa Soeiro

1457 Ritual, descarte ou afetividade? A presença de Canis lupus familiaris na Necrópole Noroeste de Olisipo (Lisboa)

Beatriz Calapez Santos / Sofia Simões Pereira / Rodrigo Banha da Silva / Sílvia Casimiro / Cleia Detry / Francisca Alves Cardoso

1467 Dinâmicas económicas em Bracara na Antiguidade Tardia Diego Machado / Manuela Martins / Fernanda Magalhães / Natália Botica

1479 Cerâmicas e Vidros da Antiguidade Tardia do Edifício sob a Igreja do Bom Jesus (Vila Nova de Gaia) Joaquim Filipe Ramos

1493 Novos contributos para a topografia histórica de Mértola no período romano e na Antiguidade Tardia Virgílio Lopes

\section{8. Época Medieval}

1511 Cerâmicas islâmicas no Garb setentrional "português": algumas evidências e incógnitas Constança dos Santos / Helena Catarino / Susana Gómez / Maria José Gonçalves / Isabel Inácio / Gonçalo Lopes / Jacinta Bugalhão / Sandra Cavaco / Jaquelina Covaneiro / Isabel Cristina Fernandes / Ana Sofia Gomes 
1525 Contributo para o conhecimento da cosmética islâmica, em Silves, durante a Idade Média Rosa Varela Gomes

1537 Yábura e o seu território - uma análise histórico-arqueológica de Évora entre os séculos VIII-XII José Rui Santos

1547 A encosta sul do Castelo de Palmela - resultados preliminares da escavação arqueológica Luís Filipe Pereira / Michelle Teixeira Santos

1559 A igreja de São Lourenço (Mouraria, Lisboa): um conjunto de silos e de cerâmica medieval islâmica

Andreia Filipa Moreira Rodrigues

1571 O registo material de movimentações populacionais no Médio Tejo, durante os séculos XII-XIII. Dois casos de "sunken featured buildings", nos concelhos de Cartaxo e Torres Novas Marco Liberato / Helena Santos / Nuno Santos

1585 O nordeste transmontano nos alvores da Idade média. Notas para reflexão Ana Maria da Costa Oliveira

1601 Sepulturas escavadas na rocha do Norte de Portugal e do Vale do Douro: primeiros resultados do Projecto SER-NPVD

Mário Jorge Barroca / César Guedes / Andreia Arezes / Ana Maria Oliveira

1619 "Portucalem Castrum Novum" entre o Mediterrâneo e o Atlântico: o estudo dos materiais cerâmicos alto-medievais do arqueossítio da rua de D. Hugo, nํ. 5 (Porto) João Luís Veloso

1627 A Alta Idade Média na fronteira de Lafões: notas preliminares sobre a Arqueologia no Concelho de Vouzela

Manuel Luís Real / Catarina Tente

1641 Um conjunto cerâmico medieval fora de portas: um breve testemunho aveirense Susana Temudo

${ }_{1651}$ Os Lóios do Porto: uma perspetiva integrada no panorama funerário da Baixa Idade Média à Época Moderna em meios urbanos em Portugal

Ana Lema Seabra

1659 O Caminho Português Interior de Santiago como eixo viário na Idade Média Pedro Azevedo

1665 Morfologia Urbana: Um exercício em torno do Castelo de Ourém André Donas-Botto / Jaqueline Pereira

1677 Intervenção arqueológica na Rua Marquês de Pombal/Largo do Espírito Santo (Bucelas, Loures)

Florbela Estêvão / Nathalie Antunes-Ferreira / Dário Ramos Neves / Inês Lisboa

1691 O Cemitério Medieval do Poço do Borratém e a espacialidade funerária na cidade de Lisboa Inês Belém / Vanessa Filipe / Vasco Noronha Vieira / Sónia Ferro / Rodrigo Banha da Silva

1705 Um Espaço Funerário Conventual do séc. XV em Lisboa: o caso do Convento de São Domingos da Cidade Sérgio Pedroso / Sílvia Casimiro / Rodrigo Banha da Silva / Francisca Alves Cardoso

\section{9. Época Moderna e Contemporânea}

1721 Arqueologia Moderna em Portugal: algumas reflexões críticas em torno da quantificação de conjuntos cerâmicos e suas inferências históricas e antropológicas Rodrigo Banha da Silva / André Bargão / Sara da Cruz Ferreira

1733 Faianças de dois contextos entre os finais do século XVI e XVIII do Palácio dos Condes de Penafiel, Lisboa

Martim Lopes / Tomás Mesquita 
1747 Um perfil de consumo do século XVIII na foz do Tejo: O caso do Mercado da Ribeira, Lisboa Sara da Cruz Ferreira / Rodrigo Banha da Silva / André Bargão

1761 Os Cachimbos dos Séculos XVII e XVIII do Palácio Mesquitela e Convento dos Inglesinhos (Lisboa)

Inês Simão / Marina Pinto / João Pimenta / Sara da Cruz Ferreira / André Bargão / Rodrigo Banha da Silva

1775 "Tomar os fumos da erua que chamão em Portugal erua sancta». Estudo de Cachimbos provenientes da Rua do Terreiro do Trigo, Lisboa

Miguel Martins de Sousa / José Pedro Henriques / Vanessa Galiza Filipe

1787 Cachimbos de Barro Caulínitico da Sé da Cidade Velha (República de Cabo Verde)

Rodrigo Banha da Silva / João Pimenta / Clementino Amaro

1801 Algumas considerações sobre espólio não cerâmico recuperado no Largo de Jesus (Lisboa) Carlos Boavida

1815 Adereços de vidro, dos séculos XVI-XVIII, procedentes do antigo Convento de Santana de Lisboa (anéis, braceletes e contas)

Joana Gonçalves / Rosa Varela Gomes / Mário Varela Gomes

1837 Da ostentação, luxo e poder à simplicidade do uso quotidiano: arqueologia e simbologia de joias e adornos da Idade Moderna Portuguesa Jéssica Iglésias

1849 Os amuletos em Portugal - dos objetos às superstições: o coral vermelho Alexandra Vieira

1865 Cerâmicas de Vila Franca de Xira nos séculos XV e XVI Eva Pires

1879 «Não passa por teu o que me pertence». Marcas de individualização associadas a faianças do Convento de Nossa Senhora de Aracoeli, Alcácer do Sal Catarina Parreira / Íris Fragoso / Miguel Martins de Sousa

1891 Cerâmica de Leiria: alguns focos de produção

Jaqueline Pereira / André Donas-Botto

1901 Os Fornos na Rua da Biquinha, em Óbidos Hugo Silva / Filipe Oliveira

1909 A casa de Pêro Fernandes, contador dos contos de D. Manuel I: o sítio arqueológico da Silha do Alferes, Seixal (século XVI) Mariana Nunes Ferreira

1921 O Alto da Vigia (Sintra) e a vigilância e defesa da costa Alexandre Gonçalves / Sandra Santos

1937 O contexto da torre sineira da Igreja de Santa Maria de Loures Paulo Calaveira / Martim Lopes

1949 A Necrópole do Hospital Militar do Castelo de São Jorge e as práticas funerárias na Lisboa de Época Moderna Susana Henriques / Liliana Matias de Carvalho / Ana Amarante / Sofia N. Wasterlain

1963 SAND - Sarilhos Grandes Entre dois Mundos: o adro da Igreja e a Paleobiologia dos ossos humanos recuperados

Paula Alves Pereira / Roger Lee Jesus / Bruno M. Magalhães

1975 Expansão urbana da vila de Cascais no século XVII e XVIII: a intervenção arqueológica na Rua da Vitória no 15 a 17

Tiago Pereira / Vanessa Filipe

1987 Novos dados para o conhecimento do Urbanismo de Faro em época Moderna Ana Rosa 
1995 Um exemplo de Arqueologia Urbana em Alcoutim: o Antigo Edifício dos CTT Marco Fernandes / Marta Dias / Alexandra Gradim / Virgílio Lopes / Susana Gómez Martínez

2007 Palácio dos Ferrazes (Rua das Flores/Rua da Vitória, Porto): a cocheira de Domingos Oliveira Maia

Francisco Raimundo

2021 As muitas vidas de um edifício urbano: História, Arqueologia e Antropologia no antigo Recreatório Paroquial de Penafiel Helena Bernardo / Jorge Sampaio / Marta Borges

2035 O convento de Nossa Senhora da Esperança de Ponta Delgada: o contributo da arqueologia para o conhecimento de um monumento identitário João Gonçalves Araújo / N’Zinga Oliveira

2047 Arqueologia na ilha do Corvo... em busca da capela de Nossa Senhora do Rosário Tânia Manuel Casimiro / José Luís Neto / Luís Borges / Pedro Parreira

2059 Perdidos à vista da Costa. Trabalhos arqueológicos subaquáticos na Barra do Tejo Jorge Freire / José Bettencourt / Augusto Salgado

2071 Arqueologia marítima em Cabo Verde: enquadramento e primeiros resultados do projecto CONCHA

José Bettencourt / Adilson Dias / Carlos Lima / Christelle Chouzenoux / Cristóvão Fonseca / Dúnia Pereira / Gonçalo Lopes / Inês Coelho / Jaylson Monteiro / José Lima / Maria Eugénia Alves / Patrícia Carvalho / Tiago Silva

2085 Trabalhos arqueológicos na Cidade Velha (Ribeira Grande de Santiago, Cabo Verde): reflexões sobre um projecto de investigação e divulgação patrimonial André Teixeira / Jaylson Monteiro / Mariana Mateus / Nireide Tavares / Cristovão Fonseca / Gonçalo C. Lopes / Joana Bento Torres / Dúnia Pereira / André Bargão / Aurélie Mayer / Bruno Zélie / Carlos Lima / Christelle Chouzenoux / Inês Henriques / Inês Pinto Coelho / José Lima / Patrícia Carvalho / Tiago Silva

2103 A antiga fortificação de Quelba / Khor Kalba (E.A.U.). Resultados de quatro campanhas de escavações, problemáticas e perspectivas futuras Rui Carita / Rosa Varela Gomes / Mário Varela Gomes / Kamyar Kamyad

2123 Colónias para homens novos: arqueologia da colonização agrária fascista no noroeste ibérico Xurxo Ayán Vila / José Mạ . Señorán Martín 


\title{
DADOS PARA A HISTÓRIA DAS MULHERES NA ARQUEOLOGIA PORTUGUESA, DOS FINAIS DO SÉCULO XIX AOS INÍCIOS DO SÉC XXI (NÚMEROS, NOMES E TABELAS)
}

\author{
Filipa Dimas ${ }^{1}$, Mariana Diniz ${ }^{2}$
}

\begin{abstract}
RESUMO
O presente artigo foca a presença das mulheres no meio arqueológico português, a partir de uma análise bibliométrica realizada a partir de duas revistas da especialidade - O Arqueólogo Português e Trabalhos de Antropologia e Etnologia - e da recolha, no Endovélico, de informação relativa à direcção, por mulheres, de escavações arqueológicas. Os resultados em ambas as revistas revelam uma presença minoritária de mulheres como expectável. Observa- se uma trajectória que se inicia abaixo do 1\%, nas primeiras décadas do século XX, para atingir valores quase paritários na segunda década do século XXI. Também os dados do Endovélico demonstram o aparecimento e crescimento efectivo da presença de mulheres, na segunda metade do séc. XX, num percurso, por vezes mais abrupto que gradual, condicionado por um conjunto de factores políticos, sociais e ideológicos. Palavras-chave: Mulheres na Arqueologia, História da Arqueologia em Portugal, O Arqueólogo Português, Trabalhos de Antropologia e Etnologia, Endovélico.
\end{abstract}

\begin{abstract}
The present article focuses on the presence of women in the field of Portuguese archaeology. Based on a bibliometric analysis of two archaeology magazines - O Arqueólogo Português and Trabalhos de Antropologia e Etnologia - as well as data gathering from Endovélico, regarding archaeological excavations directed by women. Both magazines reveal a minority presence. In which it can be seen a number that starts below $1 \%$, in the first decades of the $2 \mathrm{O}^{\text {th }}$ century, to reach almost even numbers in the second decade of the $21^{\text {st }}$ century. In addition, collection of data from Endovélico demonstrates the effective growth of women in the second half of the $2 \mathrm{O}^{\text {th }}$ century. In a path, sometimes more abrupt than gradual, due to a set of political, social, and ideological factors. Keywords: Women in Archaeology, History of Archaeology in Portugal, O Arqueólogo Português, Trabalhos de Antropologia e Etnologia, Endovélico.
\end{abstract}

\section{INTRODUÇÃO/BREVE HISTÓRIA DO TEMA}

O presente artigo foca a presença das mulheres no meio arqueológico português, a partir de uma análise bibliométrica realizada a duas publicações periódicas de grande longevidade que podem reflectir o seu trajecto, nesta ciência, ao longo do século XX e nas primeiras décadas do séc. XXI. Esta temática, com impacto tardio em Portugal, tem, no entanto, despertado um interesse crescente quer como fenómeno social amplo, quer ao nível da biografia científica de figuras particulares. Este artigo reúne dados para essa História das Mulheres, na Arqueologia,

\footnotetext{
1. Mestranda em Arqueologia da Faculdade de Ciências Sociais e Humanas, Universidade Nova de Lisboa (NOVA-FCSH); filipadimaso4@gmail.com
}

2. UNIARQ - Faculdade de Letras da Universidade de Lisboa. Associação dos Arqueólogos Portugueses. 
uma história ainda em construção. O tópico Mulheres em Arqueologia, no Passado ou no Presente, no duplo papel de actrizes e autoras da História, é como acontece com a presença feminina em Ciência, um fenómeno que, apesar de antecedentes mais remotos, surge na segunda metade do século XX, fundamentalmente a partir da década de 70 , na sequência de uma nova onda de feminismo e do aumento do número de mulheres na Universidade (Maffía, 2006). Em Arqueologia, será apenas nos anos 80 que a Arqueologia do Género, através de três personagens fundamentais - Margaret Conkey, Janet Spector e Joan Gero (Díaz-Andreu, 2014) - abre este debate, numa Ciência ainda predominantemente masculina e sexista (Wylie, 1997). Desde então, assiste-se a uma multiplicação efectiva de trabalhos sobre a matéria. Para além da realização de conferências e congressos sobre o tema (Díaz-Andreu, 2014), destacam-se obras como as de Cheryl Claasen, relativa ao panorama norte-americano (Claasen, 1994), e mais tarde, já no XXI, uma monografia dedicada às pioneiras da Arqueologia, mais uma vez no mundo ocidental (Cohen \& Joukowsky, 20o6). Em Portugal, as questões de Género são, muito tardiamente, abordadas quando analisado o cenário internacional. Só, na segunda metade da década de 9o, é publicado o primeiro artigo acerca das mulheres, na Arqueologia portuguesa, por Vítor Oliveira Jorge e Susana Oliveira Jorge, que identificam quatro etapas fundamentais nesta História (Jorge \& Jorge, 1996), à qual, hoje, têm que se somar os papeis das gerações Millenials e Geração Z.

Nas duas primeiras décadas do século XXI, é crescente o número de publicações sobre o papel das mulheres na Arqueologia Portuguesa, que como previsível, é tratado fundamentalmente, mas não exclusivamente, por autoras (Thébaud, 1996; Diniz, 2006; Maffía, 2006; Gomes, 2015), mas menos frequentes são os textos que abordam o papel das mulheres nas sociedades passadas (Diniz, 2006). A primeira periodização proposta em 1996 (Jorge \& Jorge 1996), é actualizada (Bugalhão, 2017) e são apresentadas as primeiras análises quantitativas e explorados os trajetos de figuras pioneiras - ainda excepcionais ao longo dos anos 50 e 60 , entre as quais se destacam Maria de Lourdes Costa Arthur, Irisalva Moita (Bugalhão, 2013, 2017; Martins 2016; Bastos \& Almeida 2019), a muito breve carreira arqueológica da medievalista Virgínia Rau (Melo \& Cardoso, 2014; Fernandes, 2017), ou a acção de uma estrangeira como Vera Leisner (Boaventura, 2017). Ao mesmo tempo, e para além das personagens, o quadro social da prática da Arqueologia, no Portugal contemporâneo é fonte de interesse crescente. No relatório DISCO "Discovering the Archaeologists of Europe", em 2014, as questões de Género são abordadas e quantificadas, numa comunidade constituída por $53 \%$ de indivíduos do sexo feminino (Costa et al., 2014), e, acompanhando uma tendência, Género e questões laborais passarão a fazer parte das agendas da política arqueológica (Simões et al., 2018).

Que, em Arqueologia, como em qualquer outra área de actividade, o papel das mulheres é, ao longo do século $\mathrm{XX}$, crescente, mais que uma premissa de trabalho é um pré-conceito. Dessa intervenção crescente não existem dúvidas. No entanto, para além de uma percepção social, mais ou menos generalizada e mais ou menos interiorizada, considera-se decisiva a reunião de dados que quantitativamente documentem essa História. E esse é o fundamental objectivo deste trabalho.

\section{MATERIAIS E METODOLOGIA DE ANÁLISE}

Tendo como objectivo central identificar e datar a crescente presença de mulheres na Arqueologia portuguesa, ao longo do século XX e primeiras décadas do século XXI, foi realizada uma análise bibliométrica a duas publicações periódicas fundamentais no panorama português: O Arqueólogo Português (OAP), editado pelo Museu Nacional de Arqueologia (MNA - Lisboa), e os Trabalhos de Antropologia e Etnologia editados pela Sociedade Portuguesa Antropologia e Etnologia (SPAE-Porto).

$\mathrm{Na}$ análise bibliométrica foram tidos em consideração, para cada volume analisado, os seguintes parâmetros: o número total de ocorrências de autores masculinos e femininos, contabilizados apenas uma vez, independentemente do número de artigos que assinem e da ordem em que surjam na assinatura do artigo, e a autoria dos artigos, Artigos $\mathrm{H}$ - primeiro, e único, autor homem, Artigos M - primeira, e única, autora mulher; Artigos $\mathrm{H}+\mathrm{H}-$ dois, ou mais, autores homens; $\mathrm{H}+\mathrm{M}$ e $\mathrm{M}+\mathrm{H}$ - artigos em parceria; $\mathrm{M}+\mathrm{M}-$ duas, ou mais, autoras, mulheres.

Para além desta análise foi ainda realizado um levantamento exaustivo da direcção de escavações arqueológicas conduzidas por mulheres, a partir do inventário do património arqueológico nacional - 
Endovélico (Direção-Geral do Património Cultural / DGPC). Para contextualização dos dados obtidos recorreu-se também à PORDATA.

\subsection{O Arqueólogo Português (MNA)}

A revista $O$ Arqueólogo Português (OAP), fundada em 1895, por José Leite de Vasconcelos, como órgão do, hoje, Museu Nacional de Arqueologia foi, como um dos mais antigos periódicos em continuidade no domínio da Arqueologia em Portugal, uma escolha óbvia para averiguar o género dos/as principais protagonistas, ou signatários/as, do conhecimento arqueológico produzido em Portugal.

A recolha foi realizada através da consulta da totalidade dos volumes, no site da DGPC, na secção do O Arqueólogo Português e da consulta online dos últimos volumes, através do catálogo da Biblioteca de Arqueologia e da Biblioteca do Museu Nacional de Arqueologia.

Foram utilizados os seguintes descritores, nesta recolha; Ano/ Série/Volume/N․o de ocorrências de Autores/N ․o ocorrências de Autoras/ N.․ artigos escritos por homens/ N.. Artigos escritos por mulheres/N.. artigos em parcerias exclusivamente masculinas/ N ․o. artigos em parcerias exclusivamente femininas/ №. artigos assinados por equipas mistas. Foram ainda levantados os nomes e os temas de estudo da totalidade dos signatários, dados que não serão discutidos no presente trabalho.

Os dados foram organizados, em folhas Excel, consoante as séries, Série 1 (1895-1938), Série 2 (19511964), Série 3 (1967-1977), Série 4 (1983-2008) e Série 5 (2011-2017), considerando-se como Ano do volume aquele que figura na capa, independentemente do ano efectivo de lançamento da obra.

\subsection{Trabalhos de Antropologia e Etnologia (SPAE)} A revista Trabalhos de Antropologia e Etnologia (TAE), fundada em 1919, por António Mendes Corrêa e por Joaquim Santos, ligada à Faculdade de Ciências da Universidade do Porto e ao Instituto de Antropologia (hoje Sociedade Portuguesa de Antropologia e Etnologia), foi o segundo periódico selecionado para esta análise. A sua antiguidade e longevidade, a edição na cidade do Porto torna-a mais apta a reflectir outro país arqueológico mais distante da capital, justificando a sua escolha, para esta análise que se pretende de âmbito nacional.

A recolha foi realizada através da consulta da totalidade dos volumes publicados, (1919-2019), dispo- níveis no site oficial dos Trabalhos de Antropologia e Etnologia, bem como, através do catálogo online da Biblioteca de Arqueologia. Os dados relativos ao $1^{\circ}$ Congresso de Arqueologia Peninsular foram retirados do catálogo online da Biblioteca de Arqueologia e do Dialnet e dividido em dois, sendo um ainda relativo às Actas do $1^{\circ}$ Congresso de Arqueologia Peninsular e outro apresentando o Dossier Côa.

A metodologia utilizada para os Trabalhos de Antropologia e Etnologia foi semelhante à utilizada na revista anterior, todavia, a recolha de dados foi feita por volume e fascículos. Ao contrário d'OAP, esta revista não está organizada por Séries, pelo que os dados são apresentados na sua globalidade. Desta forma, foram analisados, entre 1919 e 2019, a totalidade dos volumes já publicados, excetuando o volume 45, que não consta da base de dados oficial da revista. Foram ainda levantados os nomes e os temas de estudo da totalidade dos signatários, dados que também não serão discutidos no presente trabalho.

\subsection{Base de dados do património arqueológico/ Endovélico (DGPC)}

$\mathrm{Na}$ base de dados do património arqueológico português Endovélico (DGPC), acessível através do Portal do Arqueólogo foram procuradas na Categoria Trabalhos exclusivamente as direcções de escavações arqueológicas realizadas por mulheres, excluindo-se desta análise, por limitação do tempo, todas as outras categorias de trabalhos em que estas possam estar envolvidas, tais como: Acompanhamento; Conservação e Restauro; Estudo de Espólio; Fiscalização; Levantamento; Outros; Prospeção; Prospeção Geofísica; Relocalização/Identificação; Salvamento; Sondagem; Valorização; Verificação de achado. Nesta primeira recolha, os descritores utilizados foram: Nome/Categoria/Ano/Sítio Arqueológico/Período/Responsáveis/Co-responsáveis/ Pessoas (Relação) ${ }^{3}$, e os dados recolhidos, de forma manual, inseridos em ficheiro Excel, relativos ao período compreendido entre 1940 e 2018.

Uma segunda recolha, mais abrangente foi realizada a partir do Endovélico, para a década 2010-2019, sendo para este intervalo recolhidos todos os dados relativos a direcções de escavações realizadas por homens, por mulheres ou por equipas mistas. Esta

\footnotetext{
3. Um outro aspecto relevante, mas não abordado aqui são as co-direcções assumidas por marido e mulher ou casais não formalizados.
} 
recolha pretende dar continuidade à análise já feita até 2014, por Jacinta Bugalhão (Bugalhão 2017), ao mesmo tempo que procura dados mais finos para justificar a quebra acentuada da direcção de escavações por mulheres, registada entre 2010 e 2019.

\section{RESULTADOS}

\subsection{O Arqueológo Português - Resultados}

Para analisar a presença das mulheres na revista O Arqueólogo Português, foram recolhidos dados da $\mathrm{I}^{\mathrm{a}} \mathrm{à} 5^{\mathrm{a}}$ Série, relativos à totalidade dos volumes já publicados, entre 1895 e 2017. No total destes 122 anos, as assinaturas femininas correspondem a cerca de $21 \%$ do conjunto. Este valor médio, muito baixo, esconde, no entanto, um trajecto, de ritmo desigual, e cuja história aqui se pretende reconstituir (Tabela 1).

$1^{a}$ Série (1895-1938)

A $1^{2}$ Série tem início em 1895 e fim em 1938, e revela números esperados para a época. Em 30 volumes, apenas se regista a presença de 3 signatárias, comparativamente ao número elevado de assinaturas masculinas -463 ocorrências, que deram origem a 1213 dos artigos, número totalitário face aos três textos de autoria feminina (Tabela 1, Figura 1).

Numa revista fundada em 1895, apenas em 1919, surge a primeira assinatura feminina, Carolina Michaëlis de Vasconcelos, escreve sobre literatura, entre 1923 e 1924 e Robélia Pires de Sousa Lobo escreve sobre Augusto de Sousa Lobo. Apenas no volume relativo ao ano de 1938, mas lançado efectivamente em 1956, reaparece um texto de autoria feminina, o primeiro de temática arqueológica, de Rosa Capeans, sobre o mundo Romano.

40 anos depois do primeiro volume lançado, O Arqueólogo Português regista a presença também de uma arqueóloga portuguesa...

\section{2를 Série (1951-1964)}

A segunda série corresponde ao período entre $1951 \mathrm{e}$ 1964, em que foram publicados um total de 5 volumes, correspondendo a 47 ocorrências onomásticas. No total, registam-se 32 nomes masculinos e 15 nomes femininos (Tabela 1).

Relativamente à serie anterior, o peso das assinaturas femininas escala de forma notável para os cerca de $32 \%$, revelando um peso, precoce e de alguma forma inconsequente, de mulheres-autoras (tabela 1). De apenas três nomes de mulheres, na longíssima
$\mathrm{I}^{\underline{\mathrm{a}}}$ série registam-se agora 15 , num intervalo curto de cerca de 13 anos. Rosa Capeans, volta a estar presente, no volume de 1956, mas outros nomes surgem como o de Irisalva Moita, em 1951, num trabalho sobre mundo Romano e em 1956, sobre Pré-História, e mais tarde, em 1964, Margarida Ribeiro e Maria Cristina Moreira de Sá de Dougedroit, sobre epigrafia. Uma outra mulher, estrangeira, Vera Leisner assinará, com o marido, textos sobre Megalitismo, a partir dos anos 50.

No entanto, a análise dos valores relativos às autorias revela um outro panorama. A importância das mulheres é indiscutivelmente crescente, fazem já parte efectiva de grupos de trabalho, no terreno e no gabinete, mas como primeiras assinantes o seu peso é ainda diminuto e apenas $19 \%$ dos artigos tem uma mulher como primeira, e única, autora. Ao mesmo tempo, surgem parcerias científicas, mistas, com cerca de $7,5 \%$ dos casos, seguido das autorias conjuntas femininas, que representam cerca de $4 \%$ das assinaturas (Tabela 1, Figura 1).

$3^{\underline{a}}$ Série (1967-1977)

A $3^{\text {a }}$ série é publicada entre 1967 e 1977, e conta com 9 volumes. Tal como a anterior, esta série é curta, tendo a duração de cerca de 10 anos. Contabilizaram-se, mas excluíram-se desta análise, as notícias, textos muito breves de carácter informativo, cujo grande número, sem autoria, podia diluir o significado efectivo das assinaturas masculinas e femininas (Tabela 1). Num total de 159 autorias, o total de autorias femininas é de 36 assinaturas. Esta quebra face aos valores da $2^{2}$ Série, corresponde, no entanto a dois momentos distintos na História das mulheres, na Arqueologia portuguesa, como é visível quando se desdobram os valores obtidos para esta $3^{\underline{a}}$ Série (Tabela 1A). Nos volumes relativos a 1967-1972, a presença discreta das mulheres ronda apenas os $19 \%$. No entanto, no volume relativo aos anos de 1974-77, correspondendo ao apogeu do processo revolucionário em curso que se segue à Revolução de Abril de 74, o peso das assinaturas femininas aumenta para $37 \%$, invertendo a tendência, e projectando as mulheres como personagens decisivas na Arqueologia nacional. No total, o número de artigos com primeira, e única, autora mulher, sobe para 35, significando também aqui um crescimento substantivo da presença feminina, num momento em que a renovação social e também da comunidade arqueológica portuguesa 
integra uma componente expressiva de mulheres (Tabela 1A, figura 1).

Agora, ao lado da etnóloga Margarida Ribeiro, vinda ainda da $2^{\underline{a}}$ Série, outros nomes, alguns que serão decisivos na década de 8o, surgem pela primeira vez: Maria Adelaide Garcia Pereira, Maria Luísa Abreu Nunes, Maria Amélia Horta Pereira, Maria da Graça Amaral da Costa, Seomara da Veiga Ferreira, Maria Manuela Alves Dias, Maria Cristina Santos, Maria João Coutinho, Isilda Pires Martins, Susana Oliveira Jorge, Joaquina Soares, Ana Ramos Pereira. E a presença já tradicional do Instituto Arqueológico Alemão, em Lisboa, é assumida por Philine Kalb.

\section{4 $4^{\mathrm{a}}$ Série (1983-2008)}

Entre 1983 e 2008, são publicados 26 volumes que correspondem à $4^{\underline{a}}$ Série da revista, num total de 350 artigos. Num crescimento esperado, ainda que minoritárias, as autoras atingem os $35 \%$ do conjunto e a percentagem de artigos assinados por mulheres, como primeira, e única, autora mantém-se nos $25 \%$ do total (Tabela 1, figura 1). O lugar das mulheres é óbvio, mas minoritário. Ao longo desta longa série quase centena e meia de autoras, de forma muito desigual de volume para volume, reflectem de forma tímida as mudanças cruciais que Portugal atravessa e a comunidade arqueológica em particular com destaque para a profissionalização da Arqueologia. A presença de mulheres é muito visível nos diferentes cenários - academia, trabalhos de campo, congressos - mas a essa percepção corresponde uma (decepcionante?) percentagem de $35 \%$. Os artigos assinados por autores masculinos e femininos são dominantes na área das parcerias refletindo a natureza mista da maior parte das equipas de investigação, em Arqueologia (Tabela 1, figura 1).

\section{$5^{\text {a Série (2011-2017) }}$}

O número de autoras atinge os $45 \%$ do conjunto. Uma presença quase paritária de assinaturas masculinas e femininas é registada pela primeira vez, num contexto social em que são constantes as iniciativas para a igualdade de Género, assumida, mas ainda não alcançada. No entanto, e mais uma vez, este crescimento do número de mulheres-autoras n'OAP não se reflecte linearmente na percentagem de artigos. Quando analisados os textos escritos, dominam aqueles de autor -homem, a solo ou em equipa - em $46 \%$ dos casos - contra $29 \%$ de artigos de autoria feminina exclusiva - a solo ou em equi- pa, registando-se ainda em constante crescimento, o peso dos artigos de equipas mistas - 19\% (tabela 1, figura 1).

O gráfico da figura 2, ilustra e sustenta a proposição de partida, a do crescente, ainda que sujeito a quedas, papel das mulheres no período em análise. N'OAP depois de duas décadas de exclusividade masculina, as primeiras mulheres-autoras fazem a sua, pontual, aparição. Depois de uma longíssima $1^{\underline{a}}$ Série, três autoras em 43 anos, nos anos 50/6o, detecta-se um crescimento brusco no número de mulheres, reflexo de uma modernidade prematura e de alguma forma inconsequente. Será apenas depois da Revolução de 1974 que, de forma definitiva, a presença feminina não deixa de crescer para hoje, ainda sem atingir a paridade, rondar os $45 \%$ (Tabela 1 ).

\subsection{Trabalhos de Antropologia e Etnologia}

Em 100 anos, a percentagem de mulheres que publicaram na revista atinge os $23,8 \%$, enquanto que os homens correspondem aos 75, 9 \% restantes. Em termos de assinaturas, é expectável que esta percentagem reflita o número das autorias, uma vez que, tal como acontece com os artigos de autor único-homem-74, 6\% do total, por regra, as mulheres escrevem a solo - cerca de 9,6. Relativamente às parcerias, dominam as constituídas por signatários do sexo masculino. Todavia, artigos co-assinados entre homens e mulheres não ficam muito atrás com cerca de $4,4 \%$, mas as parcerias femininas acabam por ser inferiores ao número de artigos sem autor, com o,8\% (Tabela 2).

Em 1922, surge a primeira mulher a assinar um artigo, Amélia Bacelar, na área da Antropologia Física e Paleontologia, neste caso, em conjunto com um homem - segundo autor, e seu marido, Fernando Frade Viegas da Costa (Saldanha, 2014), inaugurando-se uma longíssima tradição, em Ciência, de parcerias de investigação e escrita, entre marido e mulher que podem - como neste caso - ou não, conservar o seu apelido de nascimento.

A presença das mulheres é ao longo de seis décadas muito escassa, e até à década de 8o, as mulheres-autoras não atingem os 10\% do conjunto (Tabela 2). Dedicam-se sobretudo às Ciências Sociais, nomeadamente às áreas da Antropologia e Demografia. O primeiro texto de natureza especificamente arqueológico, assinado no feminino, surge em 1963, da autoria de Maria Fernandes da Soledad de Castro, 
dedicado à metalurgia. Em 1969, uma estrangeira, Denise Ferembach assina um artigo dedicado à Pré-História e à Antropologia Física.

Os valores alteram-se apenas na década de oitenta quando as mulheres começam a ganhar destaque na revista, ultrapassando a barreira dos $20 \%$ das autorias (Tabela 2). No campo da Arqueologia, nomes que serão constantes nas décadas seguintes como Manuela Martins, Susana Oliveira Jorge e Salete Ponte, Raquel Vilaça, Maria de Jesus Sanches, Anabela Gomes Lebre, fazem parte de uma Nova Arqueologia portuguesa que também se define por um outro peso das personagens femininas. A dimensão internacional da Arqueologia portuguesa está também representada, Blanca García e An Lentacker assinam textos sobre temática portuguesas.

Nos anos noventa, mais especificamente a partir de 1993, nos volumes relativos à publicação das Actas do I Congresso de Arqueologia Peninsular (CAP), decorrido na Faculdade de Letras do Porto, em Outubro de 1993, as assinaturas de mulheres, de onde constam nomes - que representam diferentes gerações - como Ana Cristina Araújo, Carla Stockler Nunes, Maria de Jesus Sanches, Susana Oliveira Jorge, Eugénia Cunha, Ana Maria Silva, Teresa Alves Araújo, Carmo Marrafa, Ana Luísa Santos, Ana Isabel Santoa, Manuela Martins, Manuela Delgado, Salete da Ponte, An Lentacker, Mariana Diniz, Ana M. S. Bettencourt, Helena Catarino, Maria Isabel M. Ribeiro, Isabel Figueiral, Joaquina Soares, Ana Margarida Arruda, Jacinta Bugalhão, Raquel Vilaça, e que, pela primeira vez, atingem cerca de um terço do conjunto. Se é certo que os 33,3\% de nomes femininos constantes destas actas, refletem a composição, à data, da comunidade arqueológica ibérica e não especificamente da comunidade portuguesa, dada a natureza do I CAP, os valores dos últimos anos da década - 1996-1999, atingindo os 40\% de assinaturas femininas nos TAE, demonstra bem como outro patamar quantitativo foi efectivamente alcançado pela revista (Tabela 2, tabela 2A). O crescimento da década de 9o, consolida-se na primeira década do séc. XXI, onde, no entanto não se detectam sinais de uma paridade maior. O lugar das mulheres parece estabilizar em torno dos $33 \%$ e só na $2^{\underline{a}}$ década do séc. XXI, se vai para além dos $40 \%$ de autoras (Tabela 2).

Quanto à percentagem de artigos assinados por mulheres, a solo ou em parceria com outras mulheres, os números são sempre menos generosos e só na se- gunda década do séc.XXI, os artigos de autoras - cerca de $42 \%$ - se aproxima da percentagem de nomes femininos na revista - cerca de $44 \%$ (Tabela 2, figura 3 , figura 4). Ao longo das décadas anteriores, e ainda que os nomes de mulheres se fossem tornando progressivamente mais comuns a partir dos anos 8o, é muito baixa a percentagem de artigos de mulheres a solo ou em parceria. Esta discrepância de valores reflecte a especificidade do trajecto feminino em Ciência, que dá origem a um menor número de artigos do que os produzidos por autores-homens e os números, irrisórios, de parcerias femininas.

O gráfico da figura 4, ilustra e sustenta a proposição de partida, a do crescente papel das mulheres no período em análise. Neste caso particular, os números revelaram que a presença significativa de mulheres é inesperadamente tardia, fenómeno próprio das últimas duas décadas do séc.XX, quando se detecta uma subida abrupta dos valores que, com alguma estagnação na viragem do milénio, voltam a disparar, na segunda década do séc. XXI.

Realizando uma leitura de conjunto em ambas as revistas, como ilustram os gráficos das figs. 5 e 6 , são idênticos os pontos de partida, entre os finais do séc. XIX e as primeiras décadas do séc. XX, as mulheres são menos que pontuais nas páginas das duas publicações, e são idênticos os pontos de chegada numa, quase, paridade, as mulheres ultrapassam os $40 \%$ das autorias de artigos científicos, na segunda década do séc. XXI.

Os trajectos não são, no entanto, paralelos. Nitidamente, n'OAP (Tabela 1, Figura 5), sinais da modernidade dos meados do séc. XX fazem-se sentir - provavelmente de forma prematura e por isso os números voltam a cair até à Revolução de Abril - mas na revista do Porto, o panorama não regista alterações até aos finais da década de 70 (Figura 5, figura 6). No Portugal democrático, e num trajecto talvez mais lento que o esperado, a presença de mulheres é crescente, mas - surpreendentemente minoritária, estabilizada em torno dos $30 \%$. Um outro patamar atinge-se só na segunda década do século $\mathrm{XXI}$, e quando para muitos as questões da igualdade de género parecem já anacrónicas, a presença de mulheres ronda os $45 \%$.

\subsection{Base de dados - Endovélico}

Como referido anteriormente a recolha da base de dados do Património Cultural, Endovélico centrou-se na categoria Escavação dirigida por mulheres, 
no período compreendido entre 1940 - surge, em 1943, o primeiro nome de uma mulher - ainda que estrangeira - associada à direcção de trabalhos de campo - Vera Leisner.

Como expectável, este é também um trajecto ascendente. Os nomes de mulheres surgem pontuais na década de 40, a sua visibilidade parece, nestes domínios, menor ainda que no campo das publicações científicas e o crescimento precoce, mas não sustentado, dos anos 50 visível n'OAP, também aqui se verifica. Até quase aos finais do século XX, numa comunidade arqueológica de pequena dimensão, muito estreitamente ligada às Universidades, o número de mulheres é reduzido também. Nos anos 80 - regista-se o primeiro, e imenso, salto que se repete, antecedendo, o momento da profissionalização da classe arqueológica, nos cenários da arqueologia de contrato, dominante na primeira década do século XXI, onde as leis do mercado parecem pouco sexistas. De uma actividade marcadamente masculina, a escavação torna-se também um domínio de acção feminina (figura 7).

Uma análise conjunta dos dois gráficos (Figura 7 e 8) permite, no entanto, uma leitura mais nítida do real - se na década de 8o, o número de mulheres dispara, é de registar que elas são esmagadoramente co-responsáveis ou pessoa-relação, e apenas em pouco mais de $20 \%$ dos casos assumem a direcção plena dos trabalhos. Este quadro não sofre alterações significativas, até aos inícios do século XXI - quando o número de direcções femininas quase iguala o das co-direcções. É neste período que o relatório DISCO (Costa et al., 2014), define a comunidade arqueológica como essencialmente paritária, classificação que parece justificar-se também atendendo aos números verificados nas publicações científicas. No entanto, esta tendência de crescimento das mulheres no terreno parece inverter-se subitamente e os valores da última década em análise-2010-2018 - merecem uma análise mais detalhada. A queda muito significativa no número de trabalhos dirigidos por mulheres (Figura 7), justificou uma recolha mais abrangente da informação disponível no Endovélico para este período (Tabela 3) procurando identificar as causas desta inversão de tendência e a sua relação com as oscilações do mercado de trabalho. Admitindo-se como provável que alguns números hoje constantes do Endovélico possam ainda vir a ser alterados, os anos de 2010-2018, correspondem a um primeiro momento de crescimento-2010-2011, a uma quebra, quase para metade dos trabalhos de escavação 2012-2014, uma retoma ligeira em 2015, e números novamente em queda nos anos de 20162019. Ao longo de todo este período, as direcções femininas são sempre minoritárias - atingindo os valores máximos de 31\% em 2011, e de 35\%, em 2015 - num cenário em que dominam as direcções masculinas ou, como fenómeno de peso crescente, as equipas mistas (Figura 9).

\section{DISCUSSÃO. PARA A HISTÓRIA DAS MULHERES NA ARQUEOLOGIA, EM PORTUGAL: AS ETAPAS DE UMA PERIO- DIZAÇÃO DE CRONOLOGIA VARIÁVEL}

A partir dos dados recolhidos foi construída uma proposta de periodização (Tabela 3) para a História das Mulheres na Arqueologia Portuguesa, utilizando marcos quantitativos próprios desse percurso como limites para cada uma das quatro fases fundamentais que se identificaram: Alone in the woods, A Place in the Sun, Minority Report e Bonnie and Clyde. Estas etapas reflectem uma história das mulheres que é, nas duas revistas, muito semelhante - da invisibilidade, quase, total a uma, quase total, paridade - mas não sincrónica. Nascidas ambas as revistas, num ambiente ferozmente positivista, que é com grande probabilidade um dos momentos de mais total exclusão das mulheres dos diferentes cenários da vida pública, O Arqueólogo Português apresenta, nas primeiras décadas de existência, o ambiente próprio da Ciência masculina onde, como num clube inglês, as mulheres não entram. Numa revista fundada em 1895, a primeira mulher assina em 1921.

A primeira das quatro etapas - Alone in the woods - refere precisamente a solidão destas figuras femininas que ficam sempre aquém dos $10 \%$ do conjunto de autores, n’OAP até aos finais da 1ํérie, em 1938, e nos TAE, até ao final dos anos 70 .

Uma segunda etapa-A Place in the Sun-abre-se com

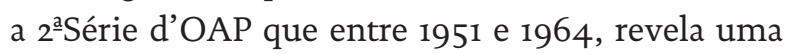
inesperada modernidade, num Portugal que ideologicamente não se renova na Europa do pós-guerra, e que permanecerá orgulhosamente só, mas onde os números reflectem - pelo menos na cidade de Lisboa - uma mudança efectiva de comportamentos e onde as mulheres-autoras, algumas antigas estudantes da Faculdade de Letras de Lisboa como Maria de Lurdes Costa Arthur ou Irisalva Moita, representarão cerca 
de $30 \%$ das assinaturas. Este protagonismo nítido, mas fácil de interromper numa comunidade de pequenas dimensões, foi n'OAP fugaz. Na revista do Porto, esta segunda fase é tardia e só na década de 80 , a percentagem de assinaturas femininas atinge os $30 \%$ do conjunto. Podem ser várias as explicações - a criação tardia da Faculdade de Letras do Porto, que só acontece em 1961, tornará mais tardia a criação, ou importação, de massa crítica, neste caso feminina, e um ambiente tradicionalmente mais conservador podem justificar as diferentes cronologias da Etapa 2, nas duas revistas.

A Etapa 3 - Minority Report - corresponde ao momento em que se detectem mais de $30 \%$ de assinaturas de mulheres, entre os autores. Esta fase corresponde n'OAP a uma muito tímida primavera marcelista, dos finais de 60/inícios da década de 70, e aos $38 \%$ de autorias femininas no volume relativo aos anos revolucionários de 1974-1977. Prolonga-se esta $3^{\circ}$ etapa n'OAP - inesperadamente - pelo longuíssimo intervalo da $4^{a}$ Série - que se estende de 1983 a 2008. Ao longo deste período de 25 anos, a sociedade portuguesa transforma-se de forma profunda. A Europeização crescente, iniciada com a adesão à CEE, em 1986, a criação de licenciaturas em Arqueologia em diferentes Universidades nacionais, a profissionalização da Arqueologia iniciada nos finais dos anos 9o, e que dá origem a um crescimento brutal da comunidade arqueológica não alteram, no entanto, estes valores. Nos TAE, serão as Actas do $1^{\circ}$ Congresso de Arqueologia Peninsular, que entre 1993 e 1995, trazem a revista para este outro patamar, onde as autorias femininas, ainda que ibéricas, ultrapassam os $38 \%$. Para muitos esta Etapa 3 parecia corresponder já a uma fase de "plena igualdade" entre sexos, num Portugal do século XXI, mas os números efectivos apontam noutro sentido, diferente do que pode ser a sua percepção social. O lugar das mulheres é agora óbvio, mas, duradouramente, minoritário.

A Etapa 4-Bonnie and Clyde, numa alusão a uma parceria célebre e verdadeiramente igualitária, atinge-se em ambas as publicações, apenas na segunda década do séc. XXI, numa demonstração clara da lentidão dos processos de mudança social. No entanto, uma percentagem de assinaturas femininas superior a 40\% não representa, agora, o atingir de um estádio de perfeição social que podia justificar o fim da História, primeiro no sentido judaico, depois marxista e por fim de F. Fukuyama. Na população portuguesa, as mulheres são mais numerosas do que os homens - correspondendo de acordo com a PORDATA, a cerca de $53 \%$ da população, pelo que numa comunidade cientifica natural - seria expectável encontrar igual proporção de autoras.

Relativamente aos dados do Endovélico, o trajecto é idêntico, mas mais uma vez não necessariamente sincrónico, com o identificado nas publicações periódicas. As direcções de trabalhos - a faceta mais claramente autoritária e masculina da actividade não são significativas antes da década de 80 e, se na escrita de textos, a autoria feminina é visível, desde os anos 50, na revista de Lisboa, as escavações permanecem como um baluarte de acção masculina.

A partir dos anos 80 e até aos finais da década seguinte, em direcção de escavações conectadas fundamentalmente com projectos de investigação, as mulheres assumem um peso crescente, mas será entre 2000-2009, acompanhando a explosão da comunidade arqueológica portuguesa que decorre da aplicação do Tratado de Malta, pelo Instituto Português de Arqueologia, que a direcção de escavações, maioritariamente realizadas no âmbito de trabalhos de Arqueologia contratual, se torna, pela acção do Mercado sem preferências de Género, uma actividade paritária.

Surpreendente, ou não, é a impressionante queda do número de mulheres a dirigir escavações, na década seguinte - entre 2012 e 2019.

A crise financeira internacional, que deflagra em 2008 e cujas mais graves consequências se farão sentir em Portugal entre 2011-2014, pode ser a mais óbvia explicação para este resultado.

No entanto, uma vez que aqui não se avalia o número de intervenções acontecidas e a sua oscilação ao longo do tempo, mas apenas o género daqueles que dirigem os trabalhos, parece claro que, como em tantos outros sectores, o emprego feminino é mais penalizado do que o masculino, nos momentos de crise económica.

Desde 2014, a retoma económica, dará origem a outro tipo de trabalhos que não a escavação e esta categoria já não é um indicador eficaz do peso do trabalho feminino, em Arqueologia. Nos últimos anos, categorias como as da Sondagem e do Acompanhamento parecem constituir o fundamental da actividade arqueológica, a analisar num outro contexto. 


\section{CONSIDERAÇÕES FINAIS}

A premissa da paridade, ou mais exactamente de um ligeiro predomínio do número de mulheres nos diferentes cenários, de que parte este texto, assume-se como como atitude fundamental, não como vingança tardia, mas como reflexo expectável de uma população natural onde as mulheres são ligeiramente maioritárias.

Os números recolhidos não deixam dúvidas quanto ao longo trajecto percorrido e não deixam também dúvidas sobre como, hoje, no Ocidente, as mulheres beneficiam, em todas as áreas, de uma longa, e internacional, batalha que construiu o Presente. Batalhas necessárias, porque os tempos, esses não mudam por eles próprios...

\section{BIBLIOGRAFIA}

BASTOS, Margarida Almeida; ALMEIDA, Rita Fragoso de (2019) - Irisalva Moita. Um percurso fotobiográfico. (J. S. Monteiro, Ed.) Lisboa: Museu de Lisboa - EGEAC, E. M. (Primeira).

BOAVENTURA, Rui (2017) - Vera.Leisner@Portugal.pt. Ophiussa, Revista do Centro de Arqueologia da Universidade de Lisboa. 1, pp. 131-142.

BUGALHÃO, Jacinta (2013) - As Mulheres na Arqueologia Portuguesa. In ARNAUD, José Morais, MARTINS, Andrea \& NEVES, César, eds. - Arqueologia em Portugal-15o anos Lisboa: Associação dos Arqueólogos Portugueses, pp. 19-23.

BUGALHÃO, Jacinta (2017) - O Papel da Mulher na Arqueologia Portuguesa. Ophiussa, Revista do Centro de Arqueologia da Universidade de Lisboa. 1, pp. 123-130.

CLAASEN, Cheryl (1994) - Women in Archaeology. (C. Claasen, Ed.) Philadelphia: University of Pennsylvania Press (First).

COHEN, Getzel M.; JOUKOWSKY, Martha Sharp (2006) - Breaking Ground. (G. M. Cohen and M. S. Joukowsky, Eds.) Ann Arbor: The University of Miching Press. (2009 ${ }^{\text {th }}$ edition).

COSTA, Cláudia; DUARTE, Cidália; TERESO, João; LAGO, Miguel; VIEGAS, Catarina; GRILO, Carolina; RAPOSO, Jorge; DINIZ, Mariana; LIMA, Alexandra (2014) - Discovering the Archaeologists of Portugal 2012-14. Associação Profissional de Arqueólogos.

DÍAZ-ANDREU, Margarita (2014) - Historia del estudio del género en Arqueología. SAGVNTVM - Papeles del Laboratorio de Arqueología de Valencia. Extra 15: Desmutant Lara Croft. Drones, Arqueología i Universitat, pp. 25-32.

DINIZ, Mariana (2006) - Para a história das mulheres na Pré-história: em torno de alguns atributos do discurso. Promontoria. 4, pp. 37-51.
FERNANDES, Hermenegildo (2017) - Virgínia Rau: Algumas variações sobre um cosmopolitismo. Faces de Eva. Estudos sobre a Mulher. 37, pp. 23-39.

GOMES, Francisco (2015) - Género, identidade e poder: para uma leitura crítica das relações de género em Arqueologia. Conimbriga. 54, pp. 27-44.

JORGE, Susana Oliveira; JORGE, Vítor Oliveira (1996) Women in Portuguese Archaeology. Trabalhos de Antropologia e Etnologia. 36, pp. 159-167.

MAFFÍA, Diana (2006) - El Vínculo Crítico entre Género y Ciencia. Clepsydra: Revista de Estudios de Género y Teoría Feminista. 5, pp. 37-57.

MARTINS, Ana (2016) - Pioneiras da Arqueologia em Portugal: «another brick» against "the wall» of indifference. Maria de Lourdes Costa Arthur (1924-2003). Clepsydra: Revista de Estudios de Género y Teoría Feminista. 15, pp.77-100.

MELO, Ana Ávila de; CARDOSO, João Luís (2014) - Virgínia Rau. Uma Medievalista na Pré-História. Estudos arqueológicos de oeiras. 21, pp. 511-546.

PORDATA - Estatísticas, gráficos e indicadores de Municípios, Portugal e Europa.

SALDANHA, Ana Rita Borba (2014) - Práticas, redes e produções científicas dos naturalistas do Museu Bocage na Europa entre guerras (1914-1945). O património documental do Arquivo MUHNAC_UL. Relatório de Estágio. Mestrado em Gestão e Valorização do Património Histórico e Cultural. Escola de Ciências Sociais. Departamento de História. Universidade de Évora.

SIMÕES, Sara; BRITO, Sara; CARVALHO, Liliana; BUGALHÃO, Jacinta; MOREIRA, Andreia (2018) - Questões de Género em Contexto Laboral em Arqueologia: breves notas. Al-madan. Adenda electrónica. 22:2, pp.111-113.

THÉBAUD, Françoise (1996) - Explorations of Gender. In DUBY, Georges, PERROT, Michelle \& THÉBAUD, Françoise, eds. - V. A History of Women. Toward a Cultural Identity in the Twentieth Century Cambridge, Massachusetts; London, England: The Belknap Press of Harvard University Press, pp. 1-13 (First)

WYLIE, Alison (1997) - The Engendering of Archaeology Refiguring Feminist Science Studies. Osiris. 12, pp. 8o-99. 
Artigos n' O Arqueólogo Português (1895-2017)

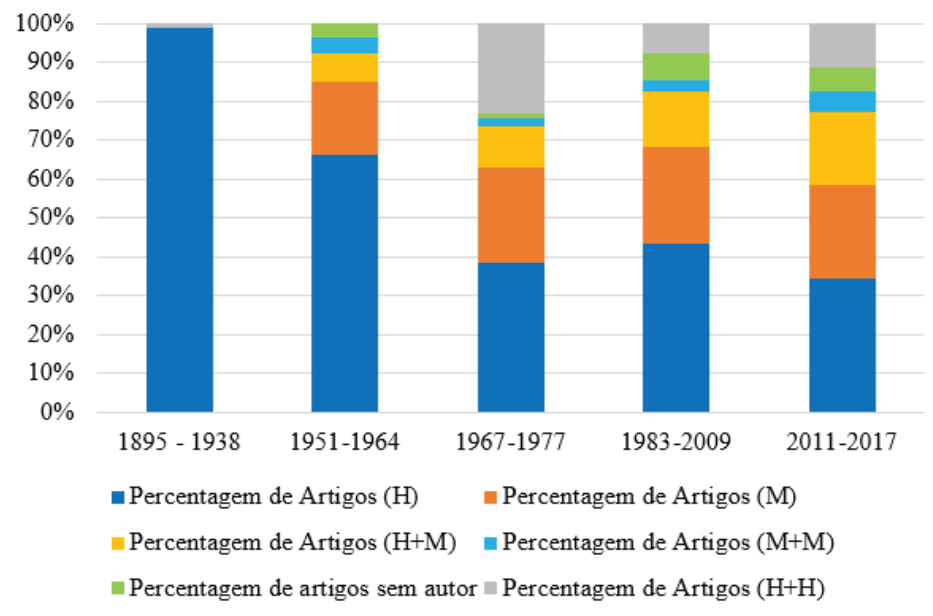

Figura 1 - Artigos n' O Arqueólogo Português - Género dos Autores.

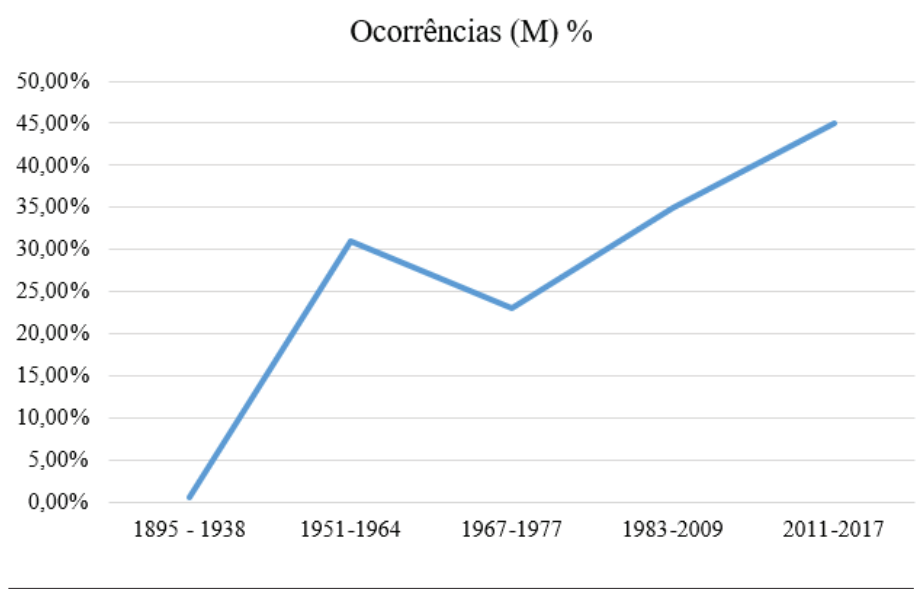

Figura 2 - Autoras n’Arqueólogo Português (1895-2017).

Artigos nos TAE (1919-2019) - género dos autores

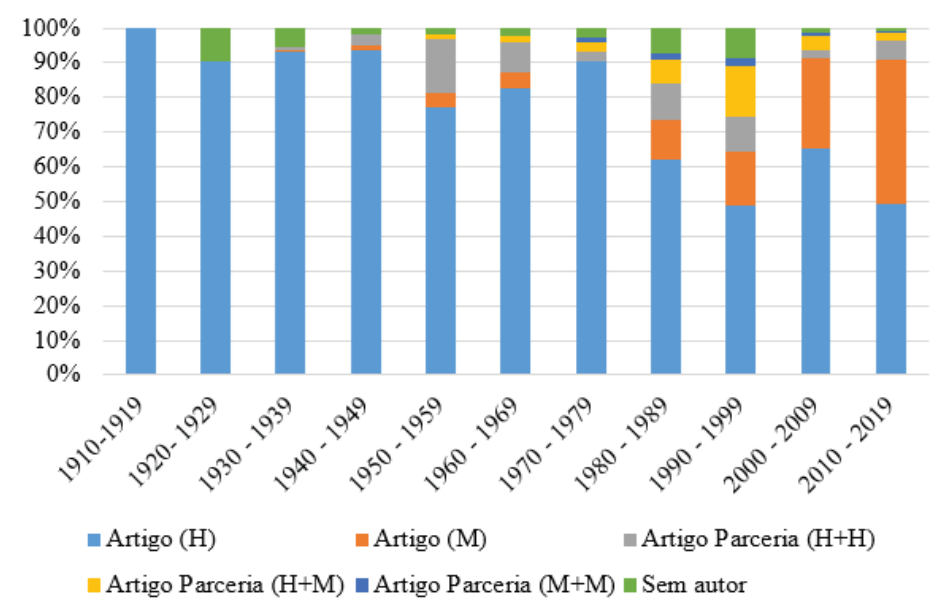

Figura 3 - Artigos nos Trabalhos de Antropologia e Etnologia (1919-2019) - Género dos Autores (1919-2019) - Género dos Autores. 


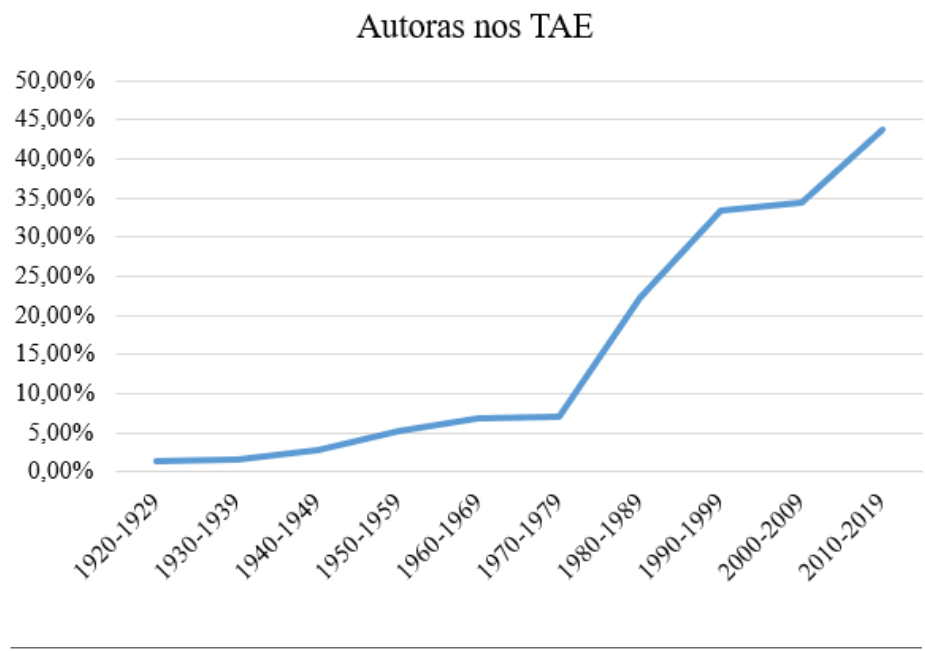

Figura 4 - Autoras nos Trabalhos de Antropologia e Etnologia (1919-2019).

Assinaturas masculinas e femininas - OAP $1^{\mathrm{a}}-5^{\mathrm{a}}$ Série (em percentagem)

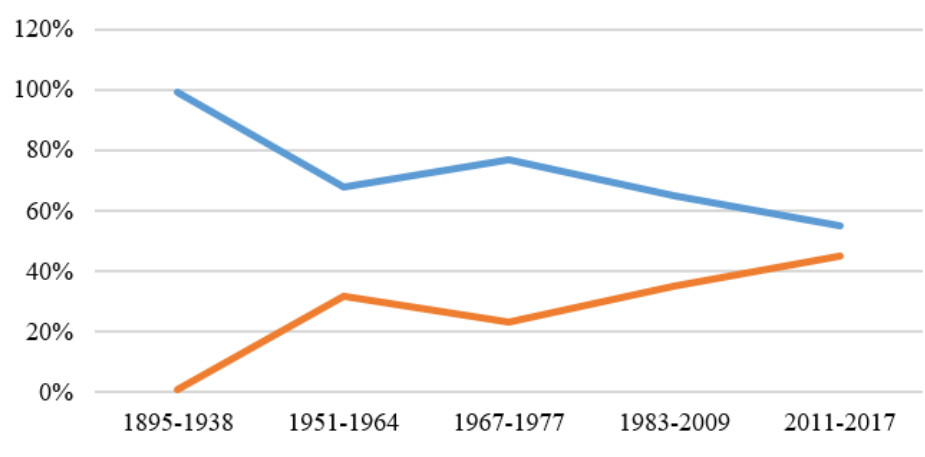

Figura 5 - Assinaturas masculinas e femininas n' O Arqueólogo Português (1895-2017).

Assinaturas masculinas e femininas - TAE 1919-2019

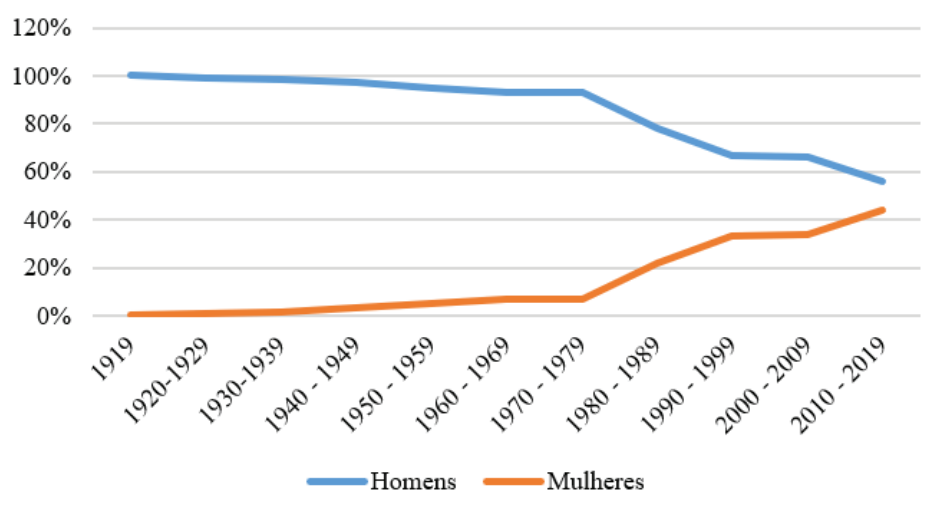

Figura 6 - Assinaturas masculinas e femininas nos Trabalhos de Antropologia e Etnologia (1919-2019). 
Escavações com direcção/co-direccão/pessoa relação de mulheres - Portal do Arqueólogo (1940-2018)

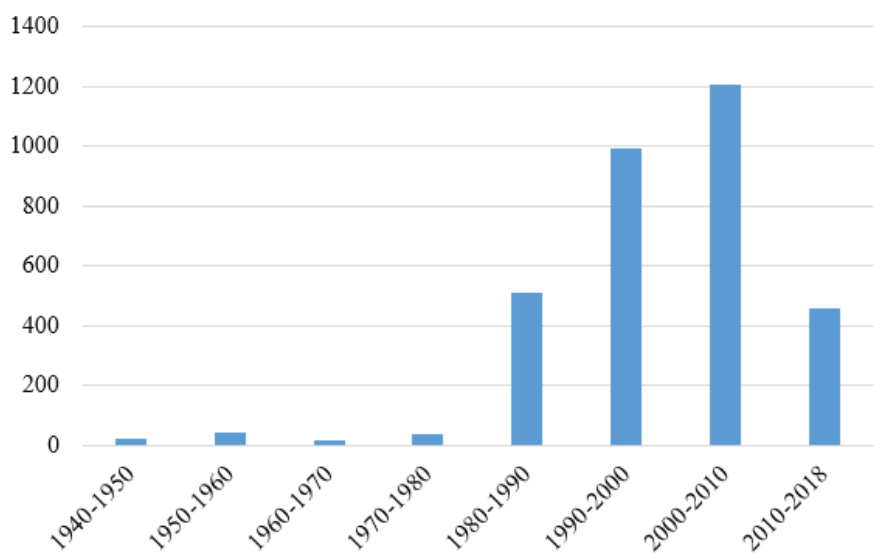

Figura 7 - Escavações com direcção / co-direcção / pessoas relação de mulheres Portal do Arqueólogo (1940-2018).

Mulheres em categorias de direcção - Portal do Arqueólogo (1940-2018)

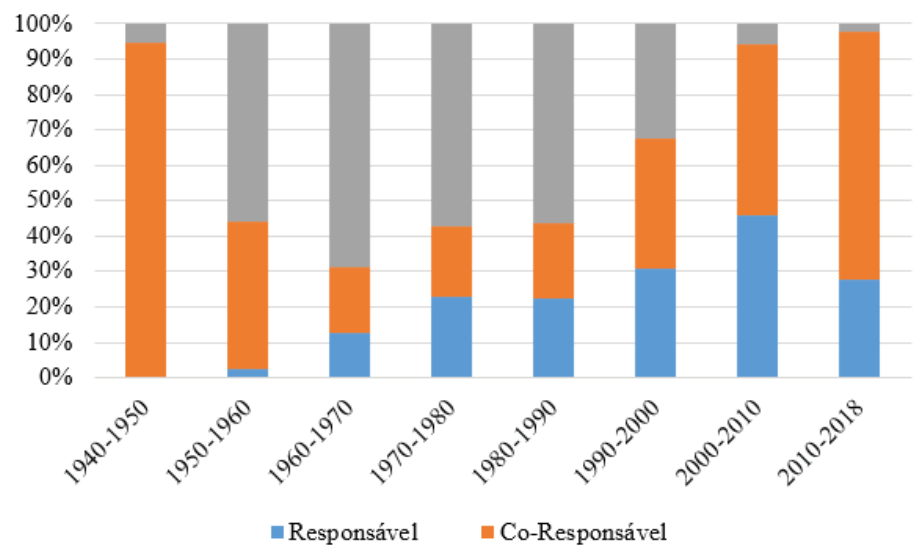

Figura 8 - Mulheres em categorias de direcção - Portal do Arqueólogo (1940-2018).

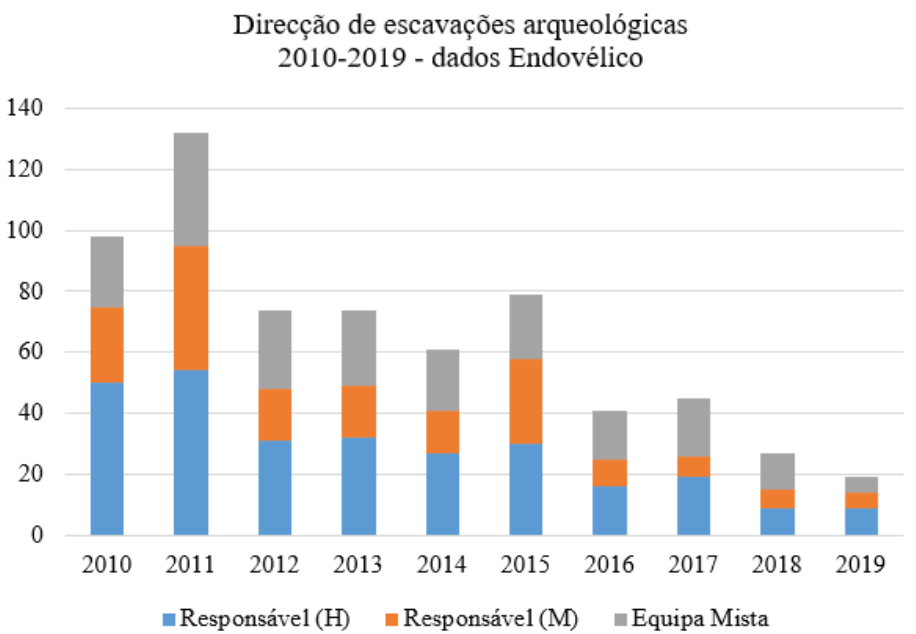

Figura 9 - Direcção de Escavações arqueológicas - 2010-2019 (Endovélico). 


\begin{tabular}{|c|c|c|c|c|c|c|c|c|c|c|c|c|}
\hline Anos & Série & $\begin{array}{c}\text { № de } \\
\text { Volumes }\end{array}$ & $\begin{array}{c}\text { Ocorrências } \\
\text { (H) }\end{array}$ & $\begin{array}{l}\text { Ocorrências } \\
\text { (M) }\end{array}$ & $\begin{array}{l}\text { Total de } \\
\text { Autores }\end{array}$ & $\begin{array}{l}\text { Artigo } \\
(\mathrm{H})\end{array}$ & $\begin{array}{l}\text { Artigo } \\
\text { (M) }\end{array}$ & $\begin{array}{c}\text { Artigo } \\
\text { Parceria } \\
(\mathrm{H}+\mathrm{H})\end{array}$ & $\begin{array}{c}\text { Artigo } \\
\text { Parceria } \\
(\mathrm{H}+\mathrm{M} \\
\mathrm{M}+\mathrm{H})\end{array}$ & $\begin{array}{c}\text { Artigo } \\
\text { Parceria } \\
(\mathrm{M}+\mathrm{M})\end{array}$ & $\begin{array}{l}\text { Sem } \\
\text { autor }\end{array}$ & $\begin{array}{c}\text { Total } \\
\text { de } \\
\text { artigos }\end{array}$ \\
\hline \multirow{2}{*}{$\begin{array}{c}1895^{-} \\
1938\end{array}$} & \multirow{2}{*}{1} & \multirow{2}{*}{30} & 463 & 3 & 466 & 1213 & 3 & 14 & $\mathrm{O}$ & $\mathrm{O}$ & $\mathrm{O}$ & 1232 \\
\hline & & & $99,4 \%$ & $0,6 \%$ & $100 \%$ & $98,5 \%$ & $0,5 \%$ & $1 \%$ & ०\% & ०\% & ०\% & $100 \%$ \\
\hline \multirow{2}{*}{$\begin{array}{l}1951- \\
1964\end{array}$} & \multirow{2}{*}{2} & \multirow{2}{*}{5} & 32 & 15 & 47 & 35 & 10 & $\mathrm{O}$ & 4 & 2 & 2 & 53 \\
\hline & & & $68,1 \%$ & $31,9 \%$ & $100 \%$ & $66,0 \%$ & $18,9 \%$ & $0,0 \%$ & $7,5 \%$ & $3,8 \%$ & $3,8 \%$ & $100,0 \%$ \\
\hline \multirow{2}{*}{$\begin{array}{l}1967- \\
1977\end{array}$} & \multirow{2}{*}{3} & \multirow{2}{*}{9} & 123 & 36 & 159 & 55 & 35 & 33 & 15 & 3 & 2 & 143 \\
\hline & & & $77 \%$ & $23 \%$ & $100 \%$ & $39 \%$ & $25 \%$ & $23 \%$ & $11 \%$ & $2 \%$ & $1,3 \%$ & $100 \%$ \\
\hline \multirow{2}{*}{$\begin{array}{l}1983- \\
2009\end{array}$} & \multirow{2}{*}{4} & \multirow{2}{*}{26} & 277 & 147 & 424 & 151 & 88 & 27 & 50 & 10 & 24 & 350 \\
\hline & & & $65 \%$ & $35 \%$ & $100 \%$ & $43,1 \%$ & $25,1 \%$ & $7,7 \%$ & $14,3 \%$ & $2,9 \%$ & $6,9 \%$ & 100\% \\
\hline \multirow{2}{*}{$\begin{array}{l}2011- \\
2017\end{array}$} & \multirow{2}{*}{5} & \multirow{2}{*}{7} & 72 & 60 & 132 & 27 & 19 & 9 & 15 & 4 & 5 & 79 \\
\hline & & & $55 \%$ & $45 \%$ & $100 \%$ & $34 \%$ & $24 \%$ & $12 \%$ & $19 \%$ & $5 \%$ & $6 \%$ & $100 \%$ \\
\hline Total & - & 77 & 967 & 261 & 1228 & 1481 & 155 & 83 & 84 & 19 & 33 & 1855 \\
\hline
\end{tabular}

Tabela 1 - O Arqueólogo Português - 1aa à $5^{\underline{a}}$ Série (1895-2017) - Valores de Género.

\begin{tabular}{|c|c|c|c|c|c|}
\hline Anos & Série & № de Volumes & Ocorrências (H) & Ocorrências (M) & Total de Ocorrências \\
\hline \multirow{2}{*}{$1967-1972$} & \multirow{2}{*}{3} & \multirow{2}{*}{4} & 91 & 21 & 112 \\
\hline & & & $81 \%$ & $19 \%$ & $100 \%$ \\
\hline \multirow{2}{*}{ 1974-1977 } & \multirow{2}{*}{3} & \multirow{2}{*}{3} & 25 & 15 & 40 \\
\hline & & & $63 \%$ & $37 \%$ & $100 \%$ \\
\hline
\end{tabular}

Tabela 1A - O Arqueólogo Português - $3^{\underline{a}}$ Série - Valores de Género 


\begin{tabular}{|c|c|c|c|c|c|c|c|c|c|c|c|}
\hline Anos & $\begin{array}{l}\text { Volumes; } \\
\text { fascículos }\end{array}$ & $\begin{array}{l}\text { Ocorrências } \\
(\mathrm{H})\end{array}$ & $\begin{array}{l}\text { Ocorrências } \\
\text { (M) }\end{array}$ & $\begin{array}{l}\text { Total de } \\
\text { Autores }\end{array}$ & $\begin{array}{c}\text { Artigo } \\
(\mathrm{H})\end{array}$ & $\begin{array}{c}\text { Artigo } \\
(\mathrm{M})\end{array}$ & $\begin{array}{l}\text { Artigo } \\
\text { Parceria } \\
(\mathrm{H}+\mathrm{H})\end{array}$ & $\begin{array}{c}\text { Artigo } \\
\text { Parceria } \\
(\mathrm{H}+\mathrm{M})\end{array}$ & $\begin{array}{c}\text { Artigo } \\
\text { Parceria } \\
(\mathrm{M}+\mathrm{M})\end{array}$ & $\begin{array}{l}\text { Sem } \\
\text { autor }\end{array}$ & $\begin{array}{l}\text { Total de } \\
\text { artigos }\end{array}$ \\
\hline \multirow{2}{*}{ 1910-1919 } & & 1 & o & 1 & 1 & o & o & o & o & o & 1 \\
\hline & & $100 \%$ & ०\% & 1 & $100 \%$ & ०\% & ०\% & o\% & ०\% & ०\% & $100 \%$ \\
\hline \multirow{2}{*}{$1920-1929$} & \multirow{2}{*}{$1 ; 4$} & 72 & 1 & 73 & 209 & o & o & 1 & o & 22 & 232 \\
\hline & & $98,6 \%$ & $1,4 \%$ & $100,0 \%$ & $90 \%$ & ०\% & ०\% & $0.5 \%$ & ०\% & $9,4 \%$ & $100 \%$ \\
\hline \multirow{2}{*}{ 1930-1939 } & \multirow{2}{*}{$4 ; 9$} & 133 & 2 & 135 & $55^{8}$ & 2 & 5 & o & $\mathrm{o}$ & 34 & 599 \\
\hline & & $98,5 \%$ & $1,5 \%$ & $100,0 \%$ & $93,1 \%$ & $0,2 \%$ & $0,8 \%$ & ०\% & ०\% & $5,6 \%$ & $100 \%$ \\
\hline \multirow{2}{*}{$1940-1949$} & \multirow{2}{*}{$9 ; 12$} & 69 & 2 & 71 & 161 & 2 & 6 & o & o & 3 & 172 \\
\hline & & $97,1 \%$ & $2,9 \%$ & $100,0 \%$ & $93,6 \%$ & $1,1 \%$ & $3,4 \%$ & o\% & ०\% & $1,7 \%$ & $100 \%$ \\
\hline \multirow{2}{*}{$1950-1959$} & \multirow{2}{*}{$12 ; 17$} & 91 & 5 & 96 & 74 & 4 & 15 & 1 & o & 2 & 96 \\
\hline & & $94,7 \%$ & $5,3 \%$ & $100,0 \%$ & $77 \%$ & $4,1 \%$ & $15,6 \%$ & $1 \%$ & ०\% & $2 \%$ & $100 \%$ \\
\hline \multirow{2}{*}{$1960-1969$} & \multirow{2}{*}{$18 ; 21$} & 69 & 5 & 74 & 77 & 4 & 8 & 2 & o & 2 & 93 \\
\hline & & $93,2 \%$ & $6,8 \%$ & $100,0 \%$ & $82,7 \%$ & $4,3 \%$ & $8,6 \%$ & 2.1 & ०\% & 2.1 & $100 \%$ \\
\hline \multirow{2}{*}{$1970-1979$} & \multirow{2}{*}{$22 ; 23$} & 40 & 3 & 43 & 66 & o & 2 & 2 & 1 & 2 & 73 \\
\hline & & $93 \%$ & $7 \%$ & $100,0 \%$ & $90,4 \%$ & ०\% & $2,7 \%$ & $2,7 \%$ & $1,3 \%$ & $2,7 \%$ & $100 \%$ \\
\hline \multirow{2}{*}{$1980-1989$} & \multirow{2}{*}{$23 ; 29$} & 133 & 38 & 171 & 119 & 22 & 20 & 13 & 4 & 14 & 192 \\
\hline & & $77,7 \%$ & $22,3 \%$ & $100,0 \%$ & $61,9 \%$ & $11,4 \%$ & $10,4 \%$ & $6,7 \%$ & $2 \%$ & $7,2 \%$ & $100 \%$ \\
\hline \multirow{2}{*}{ 1990-1999 } & \multirow{2}{*}{$30 ; 39$} & 386 & 193 & 585 & 230 & 75 & 46 & 69 & 11 & 42 & 473 \\
\hline & & $66,6 \%$ & $33,3 \%$ & $100,0 \%$ & $48,6 \%$ & $15,8 \%$ & $9,7 \%$ & $14,5 \%$ & $2,3 \%$ & $8,8 \%$ & $100 \%$ \\
\hline \multirow{2}{*}{$2000-2009$} & \multirow{2}{*}{$40 ; 49$} & 126 & 66 & 192 & 138 & 55 & 5 & 9 & 2 & 3 & 212 \\
\hline & & $65,6 \%$ & $34,4 \%$ & $100,0 \%$ & $65 \%$ & 25,9 & $2,3 \%$ & $4,2 \%$ & $0,9 \%$ & $1,4 \%$ & $100 \%$ \\
\hline \multirow{2}{*}{ 2010-2019 } & \multirow{2}{*}{$50 ; 59$} & 77 & 60 & 137 & 65 & 55 & 7 & 3 & 1 & 1 & 132 \\
\hline & & $56,2 \%$ & $43,8 \%$ & $100,0 \%$ & $49,2 \%$ & $41,6 \%$ & $5,3 \%$ & $2,2 \%$ & $0,7 \%$ & $0,7 \%$ & $100 \%$ \\
\hline \multirow{2}{*}{ Total } & \multirow{2}{*}{59} & 1197 & 375 & 1578 & 1698 & 219 & 114 & 100 & 19 & 125 & 2275 \\
\hline & & $76,1 \%$ & $23,9 \%$ & $100,0 \%$ & $74,6 \%$ & $9,6 \%$ & $5 \%$ & $4,3 \%$ & $0,8 \%$ & $5,4 \%$ & $100 \%$ \\
\hline
\end{tabular}

Tabela 2 - Levantamento de Trabalhos de Antropologia e Etnologia por década. Valores de Género.

\begin{tabular}{|c|c|c|c|c|c|}
\hline Décadas & Homens (Autores) & $\%$ & Mulheres (Autoras) & $\%$ & Total \\
\hline $1990-1992$ & 25 & $84 \%$ & 6 & $16 \%$ & $100 \%$ \\
\hline $\begin{array}{c}1993-1995 \\
\text { (Actas do I CAP) }\end{array}$ & 288 & $67 \%$ & 138 & $33 \%$ & $100 \%$ \\
\hline $1996-1999$ & 73 & $60 \%$ & 49 & $40 \%$ & $100 \%$ \\
\hline Total & 386 & $66,6 \%$ & 193 & $33,4 \%$ & $100 \%$ \\
\hline
\end{tabular}

Tabela 2A - Trabalhos de Antropologia e Etnologia na década de noventa. Valores de Género. 


\begin{tabular}{|c|c|c|c|c|c|c|}
\hline \multicolumn{7}{|c|}{ Etapas da História das Mulheres na Arqueologia Portuguesa } \\
\hline & \multicolumn{3}{|c|}{ OAP } & \multicolumn{3}{|c|}{ TAE } \\
\hline & Periodização & $\sigma^{7}$ & 0 & Periodização & $\sigma^{7}$ & 9 \\
\hline \multirow{3}{*}{1 -ALONE IN THE WOODS } & \multirow{3}{*}{$\begin{array}{c}1^{\underline{a} \text { Série }} \\
1895-1938\end{array}$} & \multirow{3}{*}{463} & \multirow{3}{*}{3} & $1919-1930$ & 93 & 1 \\
\hline & & & & $1931-1969$ & 342 & 14 \\
\hline & & & & 1971-1979 & 40 & 3 \\
\hline \multirow[t]{2}{*}{ 2-A PLACE IN THE SUN } & $\begin{array}{c}2^{2 \underline{a}} \text { Série } \\
1951-1964\end{array}$ & 32 & 15 & \multirow[b]{2}{*}{$1980-1992$} & \multirow{2}{*}{178} & \multirow{2}{*}{51} \\
\hline & $\begin{array}{c}3^{\text {a }} \text { Série } \\
1967 \text { - até } 1970\end{array}$ & 53 & 10 & & & \\
\hline \multirow{2}{*}{$\begin{array}{c}3 \text { - MINORITY REPORT } \\
\leq 40 \%\end{array}$} & $\begin{array}{c}3^{\underline{a}} \text { Série } \\
1971-1977\end{array}$ & 62 & 26 & $\begin{array}{c}\text { 1993-1995 } \\
1^{\circ} \text { Congresso de } \\
\text { Arqueologia Peninsular }\end{array}$ & 238 & 145 \\
\hline & $\begin{array}{c}4^{\underline{a}} \text { Série } \\
1983-2008\end{array}$ & 277 & 147 & $1996-2003$ & 141 & 76 \\
\hline $\begin{array}{c}4-\text { BONNIE AND CLYDE } \\
\geq 40 \%\end{array}$ & $\begin{array}{c}5^{\underline{a}} \text { Série } \\
\text { 2011-2017 }\end{array}$ & 72 & 60 & 2011-2019 & 71 & 53 \\
\hline
\end{tabular}

Tabela 3 - Etapas da História das Mulheres na Arqueologia Portuguesa. 


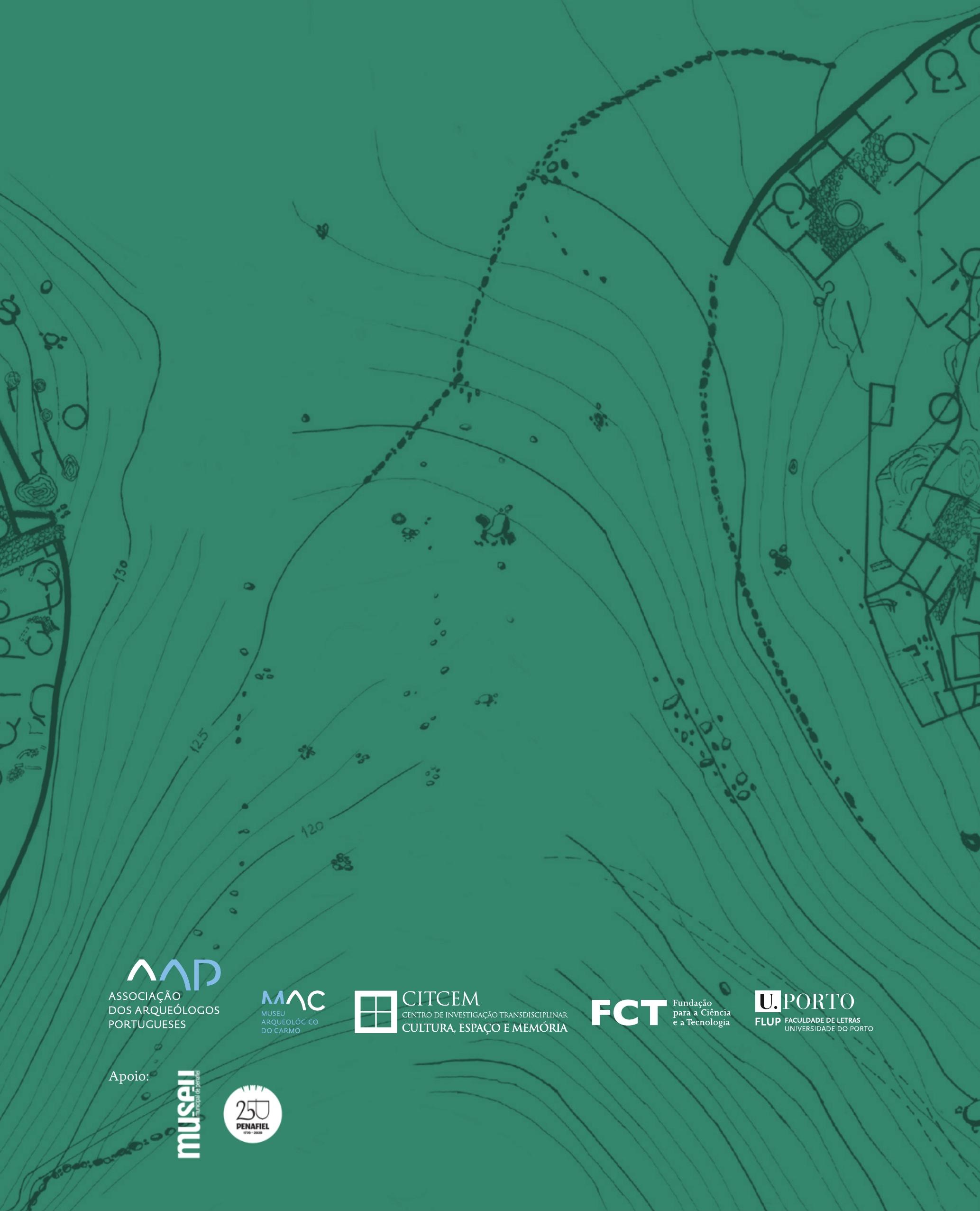

